Cornell University Law School Scholarship@Cornell Law: A Digital Repository

$11-2007$

\title{
Do Juries Add Value? Evidence from an Empirical Study of Jury Trial Waiver Clauses in Large Corporate Contracts
}

Theodore Eisenberg

Cornell Law School, ted-eisenberg@lawschool.cornell.edu

Geoffrey P. Miller

New York University Law School, geoffrey.miller@nyu.edu

Follow this and additional works at: http://scholarship.law.cornell.edu/facpub

Part of the Applied Statistics Commons, Contracts Commons, and the Corporation and Enterprise Law Commons

\section{Recommended Citation}

Eisenberg, Theodore and Miller, Geoffrey P., "Do Juries Add Value? Evidence from an Empirical Study of Jury Trial Waiver Clauses in Large Corporate Contracts" (2007). Cornell Law Faculty Publications. Paper 342.

http://scholarship.law.cornell.edu/facpub/342

This Article is brought to you for free and open access by the Faculty Scholarship at Scholarship@Cornell Law: A Digital Repository. It has been accepted for inclusion in Cornell Law Faculty Publications by an authorized administrator of Scholarship@Cornell Law: A Digital Repository. For more information, please contact jmp8@cornell.edu. 


\title{
Do Juries Add Value? Evidence from an Empirical Study of Jury Trial Waiver Clauses in Large Corporate Contracts
}

\author{
Theodore Eisenberg and Geoffrey P. Miller*
}

\begin{abstract}
We study jury trial waivers in a data set of 2,816 contracts contained as exhibits in Form 8-K filings by reporting corporations during 2002. Because these contracts are associated with events deemed material to the financial condition of SEC-reporting firms, they likely are carefully negotiated by sophisticated, well-informed parties and thus provide presumptive evidence about the value associated with the availability of jury trials. A minority of contracts, about 20 percent, waived jury trials. An additional 9 percent of contracts had arbitration clauses that effectively preclude jury trials though the reason for arbitration clauses need not specifically relate to juries. We explore three groups of factors to explain the pattern of jury trial waivers: (1) contract-specific factors: the subject matter of a contract, a measure of its standardization, choice of law, and choice of forum, (2) contracting-party factors: domestic versus international status, place of business, place of incorporation, attorney locale, and industry, and (3) factors external to the contracts and parties: perceptions of jury fairness in the forum specified in the contract and the relative length of jury and bench trial queues in that forum. Contract type is significantly associated with jury trial waivers. For example, over 50 percent of security agreements and over 60 percent of credit commitments waived jury trials. In contrast, 5 percent of employment
\end{abstract}

\footnotetext{
*Address correspondence to Theodore Eisenberg, Henry Allen Mark Professor of Law, Cornell Law School, Myron Taylor Hall, Ithaca, NY 14853; e-mail: ted-eisenberg@lawschool.cornell.edu. Miller is Stuyvesant P. Comfort Professor of Law, NYU Law School; e-mail: geoffrey.miller@ nyu.cornell.edu.

A draft of this article was presented at a workshop of the Concordia University-HEC Institute of Governance of Private and Public Organizations in Montreal. We thank attendees at the workshop, Mark Geistfeld, John Duffy, Clay Gillette, Sam Issacharoff, Florencia MarottaWurgler, Deborah Schenk, Linda Silberman, Martin Wells, and Kathryn Zeiler for comments and Natalie Erbe, Jeremy Masys, Sergio Muro, Hilel Pohulanik, Whitney Schwab, Nadav Weg, and Cathy Weist for valuable research assistance.
} 
contracts, 2 percent of bond indentures, and 3.5 percent of pooling service agreements waived jury trials. The presence of a forum selection clause, greater contract standardization, and perceived fairness of juries are significantly associated with jury trial waivers. Over 80 percent of the contracts designating Illinois as a forum contained jury trial waivers whereas less than half the contracts designating New York as a forum, and only about onethird of the contracts designating California, Texas, or Florida as a forum, contained waiver clauses. Jury trial waivers were not more common in international contracts. Our results suggest that, contrary to a widespread perception about the alleged inadequacies of juries in complex business cases, sophisticated actors may perceive that juries add value to dispute resolution.

\section{INTRODUCTION}

Commercial contracts frequently contain agreements about how the parties wish to resolve disputes that may arise under the contract. One ex ante provision for dispute resolution is an agreement to waive the right to a jury. Such waivers will ordinarily be enforced, provided they are found to be knowing and deliberate. ${ }^{1}$ Given widespread beliefs that juries do not

${ }^{1}$ The Seventh Amendment provides federal litigants with a right to jury trial in civil cases. U.S. Const. amend. VII. Many state constitutions also guarantee civil jury trial rights. See, e.g., Cal. Const. art. I, § 16 .

The right to a jury can be waived. In federal civil cases, for example, the right to jury trial is waived if not specifically demanded in timely fashion, and may also be waived by consent of both parties. FRCP Rules 38, 39. Some states, however, allow the court to reject a jury trial waiver and impose a jury on the parties in a civil case. See, e.g., Miss. Rule of Civil Procedure 38(b). Juries may also be waived in criminal cases, providing the waiver is knowing and deliberate. Such waivers are implicit in plea bargaining. See Boykin v. Alabama, 395 U.S. 238 (1969).

Federal courts also enforce predispute contractual waivers of jury trial. Waivers are implicit in agreeing to arbitration and courts generally enforce such waivers under general principles of contract law without requiring a heightened showing of consent. See, e.g., Caley v. Gulfstream Aerospace Corp., 428 F.3d 1359 (11th Cir. 2005). But see Walker v. Ryan's Family Steak Houses, Inc., 400 F.3d 370, 381 (6th Cir. 2005) (holding arbitration agreement waiver of jury right to higher standard than ordinary contract principles). Federal courts also enforce predispute jury trial waivers outside the context of arbitration agreements, at least if the agreement is knowing and voluntary. See Debra T. Landis, Contractual Jury Trial Waivers in Federal Civil Cases, 92 A.L.R. Fed. 688 (2003); Henry S. Noyes, If You (Re)Build it, They Will Come: Contracts to Remake the Rules of Litigation in Arbitration's Image, 30 Harv. J.L. \& Pub. Pol'y 579 (2007); Leasing Serv. Corp. v. Crane, 804 F.2d 828, 832 (4th Cir. 1986); K.M.C. Co. v. Irving Trust Co., 757 F.2d 752, 755 (6th Cir. 1985); Rodenbur v. Kaufmann, 320 F.2d 679, 683 (D.C. Cir. 1963); RDO Fin. Servs. Co. v. Powell, 191 F. Supp. 2d 811, 813 (N.D. Tex. 2002). But see Deborah J. 
perform well in complex commercial cases, ${ }^{2}$ we might suppose that ex ante jury trial waivers would be nearly universally observed in major business contracts.

This article reports on the first large-scale empirical study of jury trial waivers in large commercial contracts. ${ }^{3}$ We find that such waivers are far from universal. Explicit jury trial waivers were contained in only about 20 percent of the more than 2,800 contracts in our data set. Another 9 percent of contracts contained mandatory arbitration clauses. Such clauses are likely adopted for reasons other than jury avoidance. If their only purpose were to avoid a jury, this goal could be achieved more parsimoniously with a simple jury waiver. ${ }^{4}$ But even if arbitration clauses are classified as jury waivers, a substantial majority of the contracts-over 70 percent-do not preclude juries.

What causes the relative paucity of jury trial waivers in our data? Possible explanations include agency costs, strategic considerations, and transactions costs. It is also possible-perhaps likely, though difficult to prove directly-that the parties omit jury trial waivers because they believe potential jury availability adds value to the contract. Because the contracting parties in our data set are sophisticated business entities negotiating over

Matties, A Case for Judicial Self-Restraint in Interpreting Contractual Jury Trial Waivers in Federal Court, 65 Geo. Wash. L. Rev. 431, 462-63 (1997).

Most state courts also enforce predispute jury trial waivers. See Jay M. Zitter, Contractual Jury Trial Waivers in State Civil Cases, 42 A.L.R.5th 53, 71 (1996); In re Prudential Ins. Co. of Am., 148 S.W.3d 124 (Tex. 2004); Mall, Inc. v. Robbins, 412 So. 2d 1197, 1200 (Ala. 1982); L \& R Realty v. Connecticut Nat'l Bank, 715 A.2d 748, 754-55 (Conn. 1998); Malan Realty Investors, Inc. v. Harris, 953 S.W.2d 624, 626-27 (Mo. 1997) (en banc) (per curiam); Lowe Enters. Residential Partners, L.P. v. Eighth Judicial Dist. Court, 40 P.3d 405 (Nev. 2002); Rhode Island Depositors Econ. Prot. Corp. v. Coffey \& Martinelli, Ltd., 821 A.2d 222, 226 (R.I. 2003). Two states-California and Georgia-reject predispute waivers as inconsistent with applicable statutes. See Grafton Partners L.P. v. Superior Court, 116 P.3d 479 (Ca. 2005); Bank S., N.A. v. Howard, 444 S.E.2d 799 (Ga. 1994).

${ }^{2}$ See text accompanying infra notes $62-82$.

${ }^{3}$ See Robert E. Scott \& George G. Triantis, Anticipating Litigation by Contract Design, 115 Yale L.J. 814, 857 (2006) (noting that contract law scholars "focus principally on the substantive terms" of contracts rather than on ex ante mechanisms for enforcement, and characterizing the investigation of such mechanisms as a "rich avenue for future research").

${ }^{4}$ See J. Michael McGuire \& Adam S. Belzberg, Are Jury Trial Waivers Coming of Age? 38 Md. B.J. 25 (2006) (employers can avoid juries by jury trial waivers without arbitration clauses in employment contracts). 
important contracts, their revealed preferences about jury trials provides evidence bearing on the ongoing debate about the value of civil juries.

Given the variation in jury trial waivers, the question arises whether one can explain their pattern. Two major classes of factors-those internal to the contracts themselves and those external to the contracts-might help explain the pattern. At the descriptive level, we find strong associations between internal contractual factors and the rate of jury trial waivers. Contract type is the most powerful factor in describing the variation in jury trial waiver rates. Credit contracts-credit commitments and security agreements-have the highest rate of jury waiver clauses, both over 50 percent. In contrast, about 5 percent of employment contracts contain jury waivers and about 10 percent of licensing contracts contain waivers. Another factor internal to the contracts, the degree of standardization, also is associated with jury trial waivers. Contracts with low standardization are associated with lower waiver rates. The presence of a forum selection clause in the contract is also associated with jury trial waiver rates.

External forces on waiver clauses can be subdivided. Some are characteristics of the contracting parties-place of business, place of incorporation, attorney locale, and industry all might relate to the waiver rate. Other external factors are more clearly exogenous to the parties and the contract. These external factors include the perceived fairness of juries in the likely litigation forum. Parties may systematically shun juries in locales in which they perceive juries to be unfair. Expected costs of jury trials may also vary across geographical areas. Locales in which jury trials have a longer queue than bench trials increase the cost of jury trials relative to bench trials ${ }^{5}$ and may be associated with higher jury trial waiver rates. We find an association between perceived jury fairness and jury trial waiver rates but no robust association between the difference in jury and bench trial queues and waiver rates.

Section II of this article describes the relevant background to studying jury trial waivers and articulates the hypotheses relating to internal and external influences that we test. Section III describes the data and Sections IV and V report the results. Section VI discusses the results and Section VII concludes.

\footnotetext{
${ }^{5}$ State prejudgment interest rules affect the degree to which delay associated with jury trials harms plaintiffs relative to defendants. Ex ante we can assume that both contracting parties prefer prompt rather than protracted dispute resolution.
} 


\section{BAGkground And Hypotheses}

The questions of juries' value and accuracy, and in particular whether juries can competently function in complex commercial litigation, have sparked substantial academic and political debate. The business community has been hostile toward juries in tort cases, viewing juries as one of the principal causes, along with greedy plaintiffs, unscrupulous attorneys, and activist judges, of a purported litigation explosion that supposedly undermines the social fabric and the economy. Although this view has questionable empirical support, ${ }^{6}$ employers, ${ }^{7}$ large corporations, ${ }^{8}$ and residential landlords ${ }^{9}$ (among others) perceive themselves to be at risk of excessive or arbitrary jury verdicts based on hostility to deep-pocket defendants or sympathy for injured plaintiffs. According to this view, ${ }^{10}$ juries increase the risks of trials because they decide on the basis of legally irrelevant factors rather than according to the evidence and applicable law. ${ }^{11}$ Fairness concerns are accompanied by the perception that jury trials generally cost more than judge trials. Jury trials require juror selection, possible use of jury consultants, more complex evidentiary and in limine issues, and a possibly longer period to come to trial. ${ }^{12}$

${ }^{6}$ For a discussion (and rebuttal) of this view, see Marc Galanter, The Hundred-Year Decline of Trials and the Thirty Years War, 57 Stan. L. Rev. 1255, 1266 (2005). See also authorities cited infra notes 77-82.

${ }^{7}$ See Mei L. Bickner et al., Developments in Employment Arbitration, Disp. Resol. J., Jan. 1997, at $8,78-79$.

${ }^{8}$ Galanter, supra note 6 , at 1266 .

${ }^{9}$ Jury trial waivers are strongly recommended for landlords in residential lease agreements, on the theory that juries are likely to side with tenants as against deep-pocket landlords. See Alvin L. Arnold \& Jeanne O’Neill, Real Estate Leasing Practice Manual § 40:11 (2006) ("waiver by the lessee of a right to trial by jury" often appears in leases).

${ }^{10}$ This view appears to be widely shared among corporate executives and business lawyers. John Lande, Failing Faith in Litigation? A Survey of Business Lawyers' and Executives' Opinions, 3 Harv. Negot. L. Rev. 1, 51-52 (1998).

\footnotetext{
${ }^{11}$ See Galanter, supra note 6, at $1266-67$.

${ }^{12}$ Federal jury-tried cases are on the docket for shorter periods than judge-tried cases. Kevin M. Clermont \& Theodore Eisenberg, Trial by Jury or Judge: Which is Speedier? 79 Judicature 176 (Jan.-Feb. 1996); Kevin M. Clermont \& Theodore Eisenberg, Trial by Jury or Judge: Transcending Empiricism: Trial by Jury or Judge, 77 Cornell L. Rev. 1124, 1135-37 (1992). State court jury
} 
Thus, independent of perceptions of the perceived quality of juries' performance, most observers likely would regard jury trials as more costly than bench trials.

Much of the controversy about jury trials has pertained to cases between injured plaintiffs and large businesses because businesses especially fear juries' treatment in cases with sympathetic individual plaintiffs. Such cases are unlikely to arise under the contracts in our sample, with the exception of employment contracts. The studied contracts are largely between substantial corporate entities. Nevertheless, fear of juries may be observed even in corporate-dominated contracts. Juries have awarded very large damages in disputes involving businesses,$^{13}$ and business litigants may fear that juries cannot understand the legal or factual issues in a complex

trials are on the docket longer than federal court jury trials. Theodore Eisenberg, John Goerdt, Brian Ostrom \& David Rottman, Litigation Outcomes in State and Federal Courts: A Statistical Portrait, 19 Seattle L. Rev. 433, 449 (1996). Actual time in trial is on average longer in jury-tried cases than in judge-tried cases. Bureau of Justice Statistics Bulletin: Civil Justice Survey of State Courts, 2001: Civil Trial Cases and Verdicts in Large Counties, 2001 (April 2004), at 8 (4.3 days vs. 1.9 days).

${ }^{13}$ These awards, like many large awards, often are reduced or reversed. See, e.g., TXO Prod. Corp. v. Alliance Res. Corp., 509 U.S. 443, 464 (1993) (jury awarded $\$ 10$ million in business dispute); Micro/Vest v. Computerland (estimated $\$ 400$ million jury award), as reported in Computerland, N.Y. Times, June 4, 1985, and in Joni Hersch \& W. Kip Viscusi, Punitive Damages: How Juries Decide, 33 J. Legal Stud. 1, 7-8 (2006); 50-Off Stores, Inc. v. Banques Paribas (Suisse), S.A., 180 F.3d 247 (5th Cir. 1999) (jury awarded in excess of $\$ 150$ million in compensatory, consequential, and punitive damages; punitive award struck on appeal); City of Hope Nat'l Med. Ctr. v. Genentech, Inc., 20 Cal. Rptr. 3d 234, 238 (Cal. App. 2004) ( $\$ 300,164,130$ compensatory damages and $\$ 200$ million in punitive damages awarded in patent royalty dispute), review granted, 105 P.3d 543 (Cal. 2005); Rubicon Petroleum Inc. v. Amoco Prod. Co., as reported in Amoco Loses Oilfield Suit, N.Y. Times, Nov. 24, 1993 (\$417 million jury award); Time Warner Entm't Co. v. Six Flags Over Georgia, LLC, 563 S.E.2d 178 (Ga. App. 2002) (sustaining $\$ 257$ million punitive award), cert. denied, 538 U.S. 977 (2003); Pioneer Commercial Funding Corp. v. American Fin. Mortgage Corp., 855 A.2d 818 (Pa. 2004) (striking large jury award); COC Servs., Ltd. v. CompUSA, Inc., 150 S.W.3d 654 (Tex. App. 2004), review denied (June 9, 2006) (striking large punitive damages award); Amoco Chem. Co. v. Certain Underwriter's at Lloyd's of London, 1996 WL 407855 (Cal. App.) (reversing large jury award); IGEN Int'l, Inc. v. Roche Diagnostics GmbH, 335 F.3d 303 (4th Cir. 2003) (reducing award of about $\$ 505$ million by over 90 percent). In MMAR Group, Inc. v. Dow Jones $\mathcal{E}$ Co., 187 F.R.D. 282 (S.D. Tex. 1999), a jury awarded $\$ 220,720,000$ in compensatory and punitive damages. A retrial was ordered based on plaintiff discovery abuse and it is reported that MMAR eventually chose not to pursue the case. David McHam, Law \& the Media in Texas: Handbook for Journalists, available at 〈http://www.texaspress.com/Lawpress/LawMedia/Libel/TexasLibelCases.htm〉. 
civil case. ${ }^{14}$ For purposes of testing hypotheses in this article, we rely on the perception that businesses are on average expected to be anti-jury. But the real-world operation of the legal system casts doubt on any monolithic view of juries. Depending on the circumstances of a case, business defendants may choose jury trials and plaintiffs' attorneys may avoid them. ${ }^{15}$

\section{A. Jury Trial Waivers Generally}

Businesses' fear of juries' fairness, accuracy, and costs generates the hypothesis that, in a data set of contracts between sophisticated business entities, we will always, or nearly always, observe jury trial waivers. Correspondingly, the absence of a jury trial waiver clause suggests that the parties viewed jury trial availability as a positive benefit, or were indifferent as between jury and bench trials. The incidence of jury trial waivers provides a rough measure of the degree to which preserving access to juries is perceived as promoting efficiency or fairness in dispute resolution.

Hypothesis: Sophisticated parties will (nearly) always opt to waive jury trials.

\section{B. Contract-Specific Factors}

Commentators have suggested that arbitration clauses will be preferred, relative to litigation, when the legal rules are clear. ${ }^{16}$ Similarly, contracting parties who seek certainty may prefer judicial adjudication to avoid "noisy"

\footnotetext{
${ }^{14}$ Consider, for example, the issues presented in corporate control contests. See Thomas Petzinger, Jr., Oil and Honor: The Texaco-Pennzoil Wars (1987) (multibillion dollar jury award in corporate control battle).

${ }^{15}$ For example, the plaintiffs' legal strategy in the tobacco cases that generated the largest settlement in litigation history was initially designed to employ Mississippi's chancery division, in which there would be no jury. Richard P. Ieyoub \& Theodore Eisenberg, State Attorney General Actions, the Tobacco Litigation, and the Doctrine of Parens Patriae, 74 Tulane L. Rev. 1859, 1860 n.2 (2000); Doug Rendleman, Common Law Restitution in the Mississippi Tobacco Settlement, 33 Ga. L. Rev. 847, 894 (1999). In the Master Settlement Agreement, the defendants agreed to pay more than $\$ 200$ billion, fully protected against inflation, to the states. See $\langle$ http:// www.naag.org/backpages/naag/tobacco/msa).

${ }^{16}$ For discussion of the arbitration clauses, see Theodore Eisenberg \& Geoffrey P. Miller, The Flight from Arbitration: An Empirical Study of Ex Ante Arbitration Clauses in Publicly-Held Companies' Contracts, 56 DePaul L. Rev. 335 (2007); see William M. Landes \& Richard A. Posner, Adjudication as a Private Good, 8 J. Legal Stud. 235, 249 (1979).
} 
juries that are perceived as more likely to misjudge clear cases. Contracting parties may believe, ex ante, that their litigation positions will be reasonable and strong. A party who expects to have a strong case may opt for the presumably more reliable judge to vindicate its position. ${ }^{17}$ The tendency to believe in the correctness of one's position may be stronger for standardized contracts than in the case of contracts open to more interpretation. We therefore should tend to observe jury trial waiver clauses in standardized contracts. ${ }^{18}$

More generally, different contract types provide varying incentives for the parties to allow possible jury adjudication. An employment contract may raise fears in an employer's mind (or hope in the employee's mind) of a jury awarding huge amounts to a sympathetic employee. An underwriting agreement between a securities issuer and an underwriter may trigger less fear of a jury siding with a sympathetic plaintiff.

\footnotetext{
${ }^{17}$ Richard A. Posner, An Economic Approach to the Law of Evidence, 51 Stan. L. Rev. 1477, 1501 (1999); Clermont \& Eisenberg, Trial by Jury or Judge, Transcending Empiricism, supra note 12, at $1135-37$.
}

${ }^{18}$ The degree to which a contract is relational may influence the appeal of jury trials. "Presumably, expert juries are far superior to lay juries in recognizing and articulating customary practices that govern particular transactions." Robert E. Scott, The Case for Formalism in Relational Contract, in Relational Contract Theory: Unanswered Questions, A Symposium in Honor of Ian R. MacNeil, 94 Nw. Univ. L. Rev. 847, 871 (2000). Expertise in the relevant contract field appeals to contracting parties when the customary practices associated with relational contracts are likely to be at issue. They might prefer bench trials to jury trials on the theory that judges are more like experts than are juries. But see Ian R. MacNeil, Relational Contract Theory: Challenges and Queries, in Symposium, supra, 94 Nw. U. L. Rev. 877, 906 (2000) ("Even in equity, such courts [of general jurisdiction with their nonspecialist judges] are relatively poorly equipped to deal with implementation of living-contract norms, as compared to mediators, arbitrators, or specialist administrative agencies."). Contracting parties may believe a group of jurors is more likely to implement "living-contract norms" than a nonspecialized judge. It is thus unclear whether one should expect relational contracts to be associated with jury trial waivers. This theoretical ambiguity is accompanied by our inability to systematically determine whether a contract is relational. A settlement, for example, may mark the termination of a short-term or long-term relation or may be the harbinger of a continued relation. We nevertheless crudely coded for relational status based on contract categories. We coded the following contract categories as more likely to be relational: credit commitments, employment, licensing, pooling service agreements, and security agreements, and the following categories as less likely to be relational: asset sales, bond indentures, mergers, securities purchase agreements, settlements, and underwritings. In models not reported here, we found a positive significant association between relational-contract status and jury trial waiver. The results are a bit difficult to interpret. For low standardization contracts, relational contracts waive juries less. For high standardization contracts, relational contracts waive juries more. The latter result trumps the former because many more contracts are characterized as relational than nonrelational. 
Hypotheses:

1. Jury waiver clauses will be more commonly observed when contracts are standardized than when they are individually negotiated.

2. Jury waiver clauses will vary by contract type.

A contract that designates a forum opts in to a jury pool. Expectations about the potential jury pool ought to be associated with decisions about jury trial waiver clauses. We therefore expect jury trial waiver rates to vary by choice of forum. The state law chosen, like the forum, may reflect views about juror characteristics in the jurisdiction chosen compared to other jurisdictions. If the parties believe a state's juries are efficient and fair, that might reduce the costs of litigation and provide a reason to designate a jurisdiction as the choice of law.

Hypothesis: Jury waiver clauses will vary by contract choice of forum and choice of law.

\section{Party-Specific Factors}

Juries are viewed as especially threatening to "outsiders." Non-U.S. parties to contracts likely fear the U.S. legal system and may be especially fearful of U.S. juries. For example, one reason for the use of arbitration in commercial contracts is that people distrust foreign countries' legal systems. ${ }^{19}$ Foreign contracting parties, unaccustomed to legal systems with civil jury trials, would especially fear jury trials.

Hypothesis: Jury trial waivers will be observed more frequently for international contracts than for domestic contracts.

A party's business location is logically relevant to jury trial waivers because business location relates to where events under a contract might occur. The location of events influences the governing law and expected adjudication forum and, therefore, influences the jury pool that contracting parties expect to encounter. Similarly, a company's state of incorporation should be associated with the likelihood of it being sued in that state. Many

\footnotetext{
${ }^{19}$ See, e.g., Christopher R. Drahozal, Privatizing Civil Justice: Commercial Arbitration and the Civil Justice System, 9 Kan. J.L. \& Pub. Pol'y 578 (2000). But empirical evidence about U.S. court mistreatment of foreigners is lacking. Kevin M. Clermont \& Theodore Eisenberg, Xenophilia or Xenophobia in American Courts? Before and After 9/11, 4 J. Empirical Legal Stud. 441 (2007); Kevin M. Clermont \& Theodore Eisenberg, Xenophilia in American Courts, 109 Harv. L. Rev. 1120 (1996).
} 
causes of action may be brought in a company's state of incorporation. ${ }^{20}$ The incorporation state thus should be associated with increased risk of adjudication in a state's courts and exposure to the state's jury pools.

Choice of forum, choice of law, place of business, and place of incorporation can directly influence the expected jury pool. Each of these characteristics directly relates to the state in which events leading to adjudication will occur. Attorney locale likely exerts its influence indirectly, through its association with one or more of these four geographical factors. The contracting attorney's locale is especially likely to be associated with choice of law, choice of forum, and place of business. ${ }^{21}$ For example, in merger contracts, New York attorneys are more likely than other attorneys to specify a litigation forum. ${ }^{22}$ An attorney's location could influence whether a jury trial waiver clause is used if local practice influences use of such a clause.

Hypothesis: Jury waiver clauses will vary by place of business and place of incorporation.

It is less clear whether jury trial waiver rates should be expected to be associated with particular industries. Some industries likely have developed more of a tendency than others to include jury waivers. The reasons for variation across industries likely mirror some of the reasons for intercontract-type variation. An industry with more standardized contracts might seek to avoid purportedly noisy juries more than industries with more varying contracts.

Hypothesis: Jury waiver clauses will vary across industries.

\section{External Factors}

Several factors might generate interstate variation in jury trial waiver rates. The presumed cost savings of avoiding juries might vary across states. Case processing time, a proxy for costs, varies across locales. ${ }^{23} \mathrm{~A}$ busy metropolitan

\footnotetext{
${ }^{20}$ E.g., 28 U.S.C. $§ 1391$ (c) (for venue purposes, a corporation is "deemed to reside in any judicial district in which it is subject to personal jurisdiction”).

${ }^{21}$ Theodore Eisenberg \& Geoffrey P. Miller, Ex Ante Choices of Law and Forum: An Empirical Analysis of Corporate Merger Agreements, 59 Vanderbilt L. Rev. 1975 (2006).

${ }^{22} \mathrm{Id}$.

${ }^{23}$ For example, our analysis of the Bureau of Justice Statistics data covering trials in 46 counties
} 
court system may take years longer to complete a jury-tried case compared to a bench-tried case. The delay attributed to jury trials has long been associated with jury trial waiver. ${ }^{24}$ Rural court systems may have little or no backlog for either kind of trial. Empirical evidence indicates that parties choose between judge and jury trial in part based on the difference in the two trial modes' case processing time..$^{25}$ The local difference between the jury trial queue and the bench trial queue, holding other factors constant, should be associated with the rate of jury trial waivers. The greater the positive difference between expected jury and bench time to adjudication, the higher the expected jury trial waiver rate.

One also expects an association between the perceived fairness of a state's juries and the rate of jury trial waivers in contracts connected to that state. A direct connection to a state's jury pool is through a forum selection clause. Our data allow ranking states based on the jury trial waiver rates of contracts connected to the states. The Chamber of Commerce of the United States annually ranks states' juries' fairness. ${ }^{26}$ If perceptions of jury fairness explain jury trial waiver rates, states perceived to have the least fair juries should have the highest rates of jury trial waivers.

State-level rankings have an important limitation. Juries are selected at the county or judicial district level, not at the state level. Using states as the unit of observation, for example, groups rural upstate New York counties with the Bronx and Manhattan. These geographic units obviously may differ in their litigation and jury characteristics. Nevertheless, the Chamber's ranking exists at the state level and supplies an empirically testable hypothesis.

Hypotheses:

1. Jury waiver clauses will be more commonly observed when adjudication will be in states with longer adjudication time for jury trials than for bench trials.

in 2001, discussed at text accompanying infra notes 49-54, indicates that the mean number of months from filing to disposition was 44.4 in Worcester, Massachusetts and 11.3 in Fairfield, Connecticut.

${ }^{24}$ Hans Zeisel, The Jury and Court Delay, 328 Annals Am. Acad. Pol. \& Soc. Sci. 46 (1960).
${ }^{25}$ Clermont \& Eisenberg, Trial by Jury or Judge, Transcending Empiricism, supra note 12, at
$1145-48$.

${ }^{26}$ E.g., U.S. Chamber of Commerce State Liability Systems Ranking Study, Final Report, Jan. 11, 2002 (Study No. 14966). 
2. Jury waiver clauses will be more commonly observed in contracts connected to states perceived as having unfair juries.

Some important factors affecting whether to waive a jury trial are not readily observable. For example, the waiver decision in a specific contract depends on the parties' perceptions of the relative advantages to them of jury versus judge adjudication. Perceived advantages may stem from local characteristics, from perceptions of judges and juries, from projections about where adjudication might occur, from contract-specific relative cost projections, and from other factors not observable by us.

\section{The Data}

The data consist of 11 types of contracts contained as exhibits to Form 8-K "current report" filings with the Securities and Exchange Commission (SEC) for several months in 2002, plus a miscellaneous contract category designated as "Other." Reporting firms must file Form 8-K to disclose, inter alia, material agreements that have not previously been reported by the company. ${ }^{27}$ For 11 contract categories, six months of contracts, covering the period January 1 to June 30, 2002, were studied. For merger contracts, the study covered a seven-month period from January 1 to July $31,2002 .{ }^{28}$ We searched for all Form 8-K filings and coded the material contracts that were exhibits to the filings. The resulting sample consisted of 2,816 contracts. $^{29}$

\footnotetext{
${ }^{27}$ SEC Form 8-K, Current Report, Item 1.01 (Entry into a Material Definitive Agreement). 17 C.F.R. $\$ 229.601$ (a) suggests that a Form 8-K exhibit is required when relevant to the Form 8-K current report filing. "A Form 8-K Exhibit is required only if relevant to the subject matter reported on the Form 8-K report." Id. (n.5 to exhibit table).
}

${ }^{28}$ The expanded period for merger contracts exploits our earlier work on choice of law and choice of forum in merger contracts. Eisenberg \& Miller, Merger, supra note 21.

\footnotetext{
${ }^{29}$ Some material contracts may appear in Form 10-K filings and not in Form 8-K filings, but we found that Form 8-K exhibits more consistently yielded material contracts than did Form 10-K exhibits. For example, the following LexisNexis EDGAR PLUS search: Exhibit and ("material contract") and FILING-DATE aft (12/31/2001) and FILING-DATE BEF (2/1/2002) and FORM-TYPE (10-K), yielded 564 documents with references to material contracts but most contracts are outside the time period of interest and many contracts are noted but not attached as exhibits. In contrast, the following search: Exhibit and ("material contract") and FILINGDATE aft (12/31/2001) and FILING-DATE BEF (2/1/2002) and FORM-TYPE (8-K), yielded 758 documents, almost all of which are in the time period of interest. We think it unlikely that differences in the patterns of contract constituting exhibits to Forms $8-\mathrm{K}$ and $10-\mathrm{K}$ would
} 
Table 1: Types of Contracts Studied (Number of Contracts in Parentheses)

\begin{tabular}{ll}
\hline Asset sale/purchase (314) & Other (464) \\
Bond indentures (155) & Pooling and servicing (173) \\
Credit commitments (217) & Securities purchase (461) \\
Employment (111) & Security agreements (37) \\
Licensing (48) & Settlements (72) \\
Mergers (412) & Underwriting (352)
\end{tabular}

Source: SEC EDGAR database, LEXIS EDGAR PLUS database, January 2002 to June 30, 2002 for all contract types other than mergers and January 2002 to July 31, 2002 for merger contracts.

Table 1 lists the types and contracts studied and the number of contracts with information about the presence of a jury trial waiver clause. Most of the contract types are self-explanatory. "Pooling and servicing" contracts are used in mortgage pass-through and other asset-backed securities arrangements; they represent agreements under which an owner transfers receivables to a trustee that holds title to and collects the income from the assets and passes the funds through to investors. ${ }^{30}$

Securities purchase agreements were the most frequent contract type (excluding the residual category "Other") and accounted for 16.4 percent of

materially bias our results. The Form 8-K search also yields many duplicative documents. For example, America West Holdings Corp. had 12 filings on January 31, 2002, eight of which contain "Material Contracts" exhibits and four of which contain "Rights of Security Holders" exhibits. These appear to relate to an integrated transaction arising out of U.S. Airways' bankruptcy. So not all exhibits to Form 8-K were included in our sample.

${ }^{30}$ E.g., Circuit City Credit Card Master Trust, Form 8-K, Exh. 4.2, Amended and Restated Master Pooling Service Agreement, Dated as of December 31, 2001, filed Jan. 31, 2002, Doc. No. 02523859, at 21-22. See generally Thomas E. Planck, The Security of Securitization and the Future of Security, 25 Cardozo L. Rev. 1655 (2004). Trust agreements establish these trusts. E.g., First Consumers National Bank, Form 8-K, Exh. 4.3, Trust Agreement Between First Consumers Credit Corporation, as Seller, and Bankers Trust Company, as Owner Trustee, Dated as of March 1, 2001, and amended and restated as of December 31, 2001, filed Jan. 31, 2002, Doc. No. 02524022. One assumes that no jury trial right exists for many issues arising under trust agreements because of trusts' link to equity jurisdiction. E.g., Mertens v. Hewitt Assocs., 508 U.S. 248, 256 (1993) ("at common law, the courts of equity had exclusive jurisdiction over virtually all actions by beneficiaries for breach of trust"); Beacon Theatres, Inc. v. Westover, 359 U.S. 500 (1959) (addressing relation between a claim's historical origins and the right to jury trial). Trust agreements may have less need for jury trial waivers than contracts that can be enforced by actions at law. We exclude trust agreements from this study because jury trials would be unavailable for many trust-related disputes that sought traditional equitable relief. 
the total of 2,816 contracts. Credit-related contracts-bond indentures, credit commitments, pooling and servicing agreements, and security agreements-accounted for about another 21 percent of the contracts. Merger contracts were about 15 percent of the sample, but note that they had one extra month of coverage in the data. Together, the contract types offer a reasonably rich variety of relations. Several types, including the credit-related contracts, obviously involve substantial financial institutions. Others types, asset sale/purchase and merger contracts, involve corporate restructurings. Settlements involve resolution of disputes. Employment contracts offer insights into jury waiver clauses in agreements between key individual employees and large corporate employers.

\section{Bivariate Results}

We test the hypotheses that waivers of jury trial will be: (1) regularly observed in contracts involving sophisticated business entities, (2) more frequently observed in standardized as compared with individually negotiated contracts, (3) associated with choice of forum or choice of law, (4) more frequently observed in international contracts, (5) associated with place of business, place of incorporation, or attorney locale, (6) associated with industrial classification, (7) more frequently observed in states regarded as having less fair juries, and (8) more frequently observed in states with longer queues to jury trials relative to bench trials.

\section{A. Frequency of Jury Trial Waivers by Contract-Specific Factors}

\section{Type of Contract}

Table 2 shows that sophisticated actors do not systematically flee juries. Column 2 indicates that only about 20 percent of more than 2,800 contracts waive jury trials. Substantial variation exists across contract types in waiver rates. Jury trials were waived in about 2-6 percent of bond indenture, employment, pooling service, and underwriting contracts, but in about 65 percent of credit commitments and 54 percent of security agreements.

Columns 3 and 4 account for the relation between arbitration clauses and jury trial access. Arbitration clauses implicitly waive any right to jury trial. However, unlike explicit jury trial waivers, which are hostile to juries, arbitration clauses opt out of all litigation. So an arbitration clause may reflect a dislike of judges as decisionmakers instead of or in addition to juries, or a 


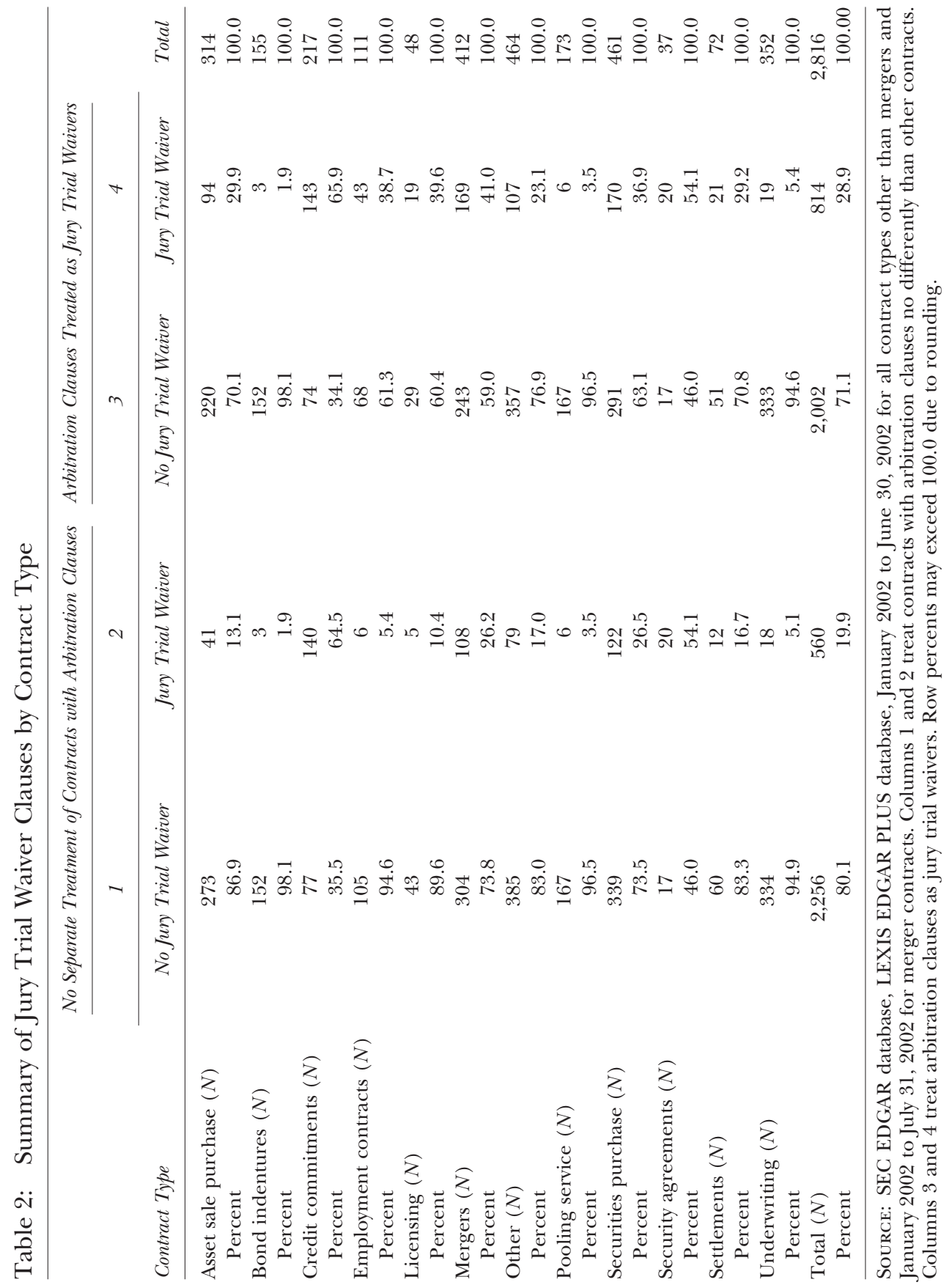


wish to avoid other aspects of civil trials not associated with the jury. Accordingly, an arbitration clause is a form of jury trial waiver, subject to the caveat that foregoing trials likely is not driven by the wish to avoid juries. Otherwise, the parties could simply waive the jury without using an arbitration clause. ${ }^{31}$

Columns 3 and 4 show results if one equates arbitration clauses with jury trial waivers. The waiver rate then increases from 19.9 percent to 28.9 percent, ${ }^{29}$ but the vast majority of contracts continue not to waive jury trials. Characterization of the arbitration clauses does not materially affect the contract categories that most frequently expressly waive jury trials-credit commitments and security agreements. However, other contract categories do materially change. Employment contracts go from 5.4 percent to 38.7 percent jury trial waivers, and notable increases result for licensing and settlement agreements.

\section{Contract Standardization}

We hypothesized that increasing contract standardization is positively associated with jury trial waiver rates. Prior work found an inverse association between contract standardization and the use of arbitration clauses. ${ }^{32} \mathrm{We}$ again use an objective measure of standardization, the distribution of the choice of law pattern for each contract type. A contract type that regularly specifies one choice of law likely has achieved greater standardization than a class of contract that designates many choices of law. ${ }^{33}$ As shown below, the results of categorizing using our standardization measure appear quite plausible. Highly regularized financial transactions, such as pooling and servicing agreements and trust agreements, score high in standardization. Less regularized transactions, such as settlements and licensing agreements, have low standardization.

We assess choice-of-law-based concentration to proxy contract standardization by focusing on three states, New York, Delaware, and California.

\footnotetext{
${ }^{31}$ Interestingly, we find no significant difference in the rate of jury trial waivers based on whether an arbitration clause was included in the contract: 20.5 percent of 2,449 contracts without arbitration clauses waived jury trial compared to 17.0 percent of 295 contracts with arbitration clauses $(p=0.166)$. Excluding contracts with arbitration clauses from the calculation yields a waiver rate of 20.5 percent.

${ }^{32}$ Eisenberg \& Miller, Arbitration, supra note 16.

${ }^{33}$ As we earlier noted, it is theoretically possible for contracts to be completely standardized in all other terms and vary only in choice of law, but that is not likely to be the general tendency.
} 
Figure 1: Distribution of choice of law by contract type.
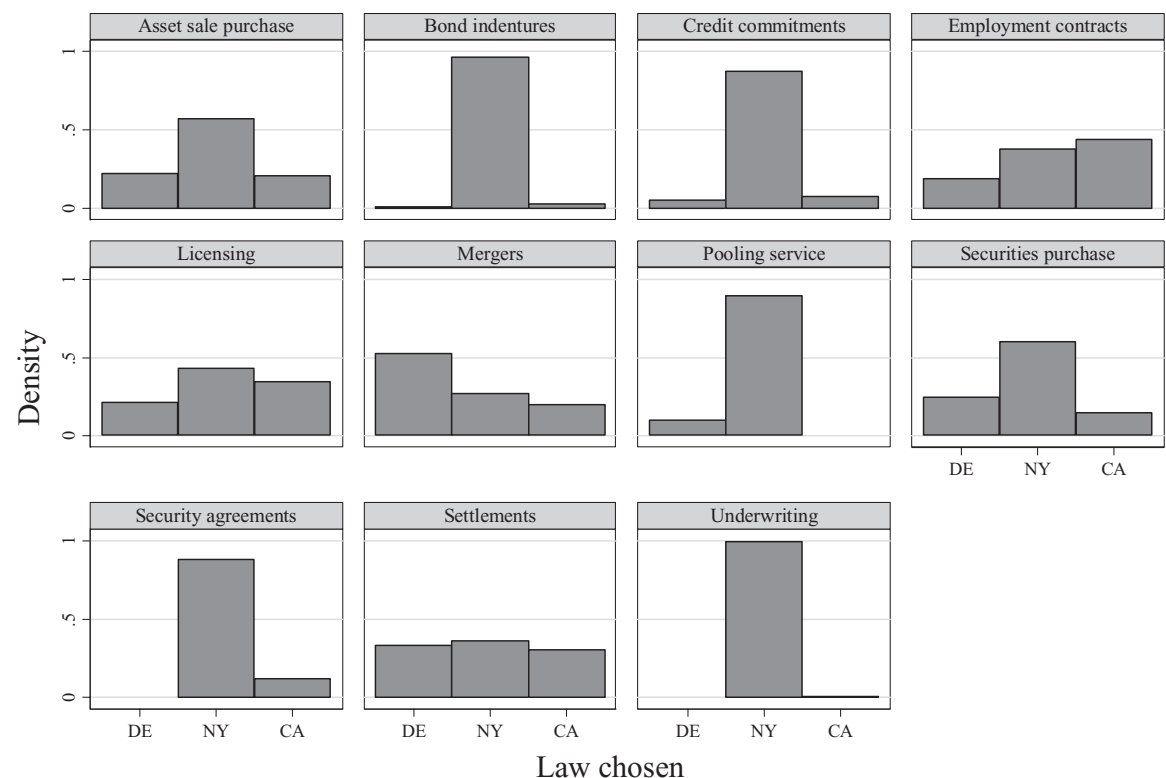

Source: SEC EDGAR database, LEXIS EDGAR PLUS database, January 2002 to June 30, 2002 for all contract types other than mergers and January 2002 to July 31, 2002 for merger contracts. Each histogram shows the distribution of contracts by choice of law. Contracts designating Delaware, New York, or California law are included. All other contracts are coded as designating an "Other" choice of law and not used in the standardization computation.

These three states account for the choice of law in approximately 70 percent of the contracts in our sample, with New York accounting for 47 percent, Delaware 14 percent, and California 8 percent. The choice of law is otherwise widely dispersed across many locales and these locales can be excluded without unduly compromising our measure of concentration. No other locale accounts for even 4 percent of the choices of law. We use the degree of concentration among the three leading states to classify contracts as having high, medium, or low standardization rates.

Figure 1 shows, for 11 contract categories (the category "Other" is excluded from this analysis because of its heterogeneity), the distribution of choice of law among New York, Delaware, and California. Bond indentures, credit commitments, underwriting contracts, pooling service agreements, and security agreements all have high choice of law concentrations. For example, nearly all bond indentures and underwriting contracts designate New York law as the governing law. 
Figure 2: Contract standardization, jury waivers, and arbitration clauses.

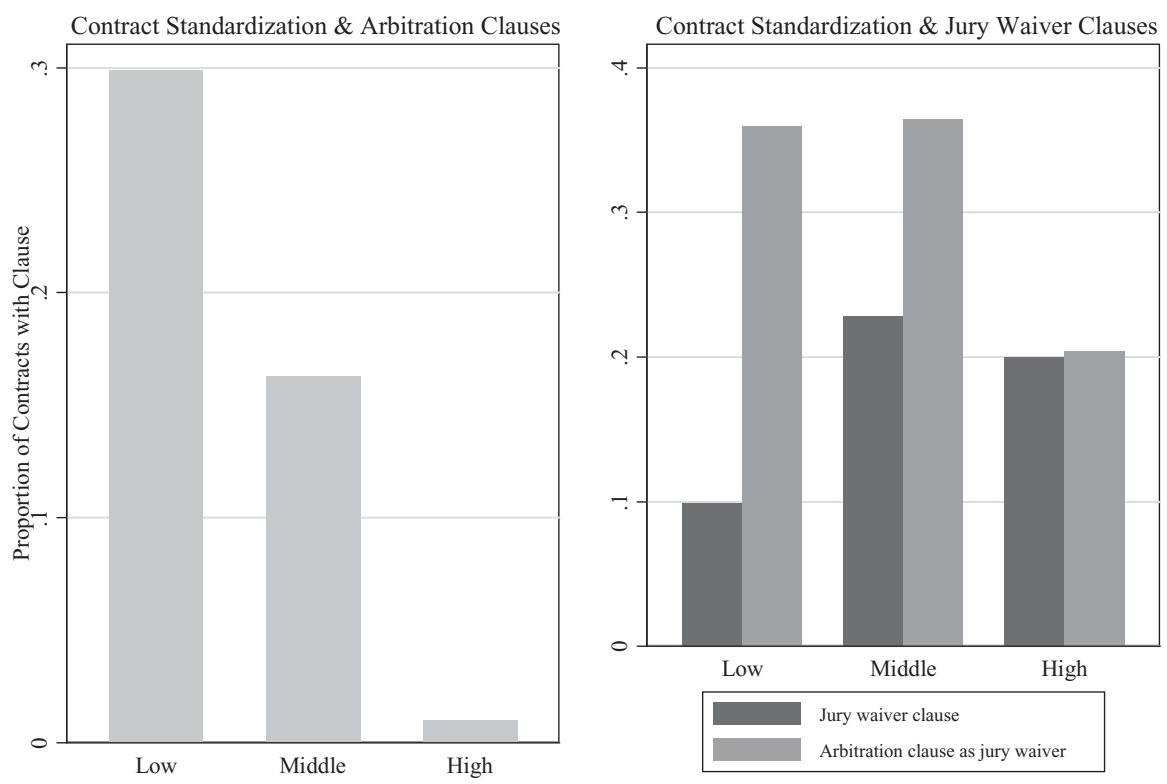

Source: SEC EDGAR database, LEXIS EDGAR PLUS database, January 2002 to June 30, 2002 for all contract types other than mergers and January 2002 to July 31, 2002 for merger contracts. Contract standardization is described in text and Figure 1. "Arbitration clause as jury waiver" codes the waiver as 1 when a contract contains an arbitration clause. Excludes contracts classified as "Other."

We treat mergers, securities purchase agreements, and asset sale purchase agreements as having medium concentrations. Each has a concentration (or density) exceeding 0.5 in one state, but these three contract types are not as concentrated as the highly concentrated group. Settlements, employment contracts, and licensing agreements have low choice of law concentrations. None has a density of 0.5 .

Figure 2 explores the relation between standardization and the rate of jury trial waiver clauses. The figure's left side shows the relation between contract standardization and the rate of arbitration clause use. As earlier reported,$^{34}$ there is a definite trend. The relation between standardization and jury trial waivers is less monotonic, as shown in Figure 2's right side. Jury trial waiver rates are lowest in low standardization contracts and highest in

\footnotetext{
${ }^{34}$ Eisenberg \& Miller, Arbitration, supra note 16.
} 
contracts with mid-level standardization. Jury trial waiver occurs in 23 of 226 (10.2 percent) of low standardization domestic contracts and in 411 of 2,067 (19.9 percent) of medium or high standardization domestic contracts. The difference is highly statistically significant $(p<0.001)$. The second set of bars on Figure 2's right side, those labeled "Arbitration clause as jury waiver," shows that the standardization-waiver pattern changes if one characterizes arbitration clauses as jury trial waivers. The strong arbitration clause pattern shown on the left side of the figure dampens the pattern in non-arbitrationclause contracts.

If one excludes contracts with arbitration clauses from consideration (other than those expressly waiving jury trials), thereby treating them as neither jury trial waivers nor non-jury trial waivers, the pattern in the bars labeled "Jury waiver clause" reemerges. Then, waiver rates are significantly different in low standardization contracts compared to medium or high standardization contracts (14 of 159 (8.8 percent) vs. 413 of 1,870 (22.1 percent; $p<0.001)$ ). Thus, those who want to use the court system, as evidenced by a no-arbitration clause, tend to opt for bench trials in more highly standardized contracts.

\section{Contract Choice of Forum}

We hypothesized that jury trial waiver rates would vary by choice of forum. Table 3 reports jury trial waiver rates as a function of choice of forum. It aggregates all states chosen as a forum in fewer than 20 contracts as "Other." Interstate variation exists, with over 80 percent of contracts specifying Illinois as a choice of forum waiving jury trials and contracts specifying California, Texas, or Florida as the forum waiving jury trials about one-third of the time. ${ }^{35}$ Delaware, Massachusetts, New York, and Ohio are between the extremes. Assuming that most major contracts in Illinois have a connection to the Chicago area, the high waiver rate likely reflects a view of Chicago juries (although note that there were only 37 total contracts specifying an Illinois forum).

Interstate variation notwithstanding, Table 3's most revealing feature is the difference between contracts that do and do not specify a forum. All the major states specified as a forum have jury trial waiver rates of at least 33

\footnotetext{
${ }^{35}$ For purposes of this analysis, we do not distinguish between federal and state courts within a state. Many contracts provided for the state or federal courts within a state as the designated forum.
} 
Table 3: Jury Trial Waiver Rates and Contract Choice of Forum

\begin{tabular}{|c|c|c|c|c|c|c|}
\hline \multirow[b]{2}{*}{ Choice of Forum } & \multicolumn{3}{|c|}{$\begin{array}{l}\text { No Separate Treatment of } \\
\text { Contracts with Arbitration Clauses }\end{array}$} & \multicolumn{3}{|c|}{$\begin{array}{l}\text { Arbitration Clauses Treated } \\
\text { as Jury Trial Waivers }\end{array}$} \\
\hline & $\begin{array}{l}\text { N No Jury } \\
\text { Trial Waiver }\end{array}$ & $\begin{array}{l}\mathrm{N} \text { Jury } \\
\text { Trial Waiver }\end{array}$ & $\begin{array}{l}\text { Rate } \\
(\%)\end{array}$ & $\begin{array}{l}\text { N No Jury } \\
\text { Trial Waiver }\end{array}$ & $\begin{array}{l}\mathrm{N} \text { Jury } \\
\text { Trial Waiver }\end{array}$ & $\begin{array}{l}\text { Rate } \\
(\%)\end{array}$ \\
\hline CA & 47 & 26 & 35.6 & 38 & 35 & 47.9 \\
\hline DE & 67 & 53 & 44.2 & 58 & 62 & 51.7 \\
\hline FL & 28 & 16 & 36.4 & 28 & 16 & 36.4 \\
\hline IL & 7 & 30 & 81.1 & 5 & 32 & 86.5 \\
\hline MA & 14 & 12 & 46.2 & 10 & 16 & 61.5 \\
\hline $\mathrm{NY}$ & 236 & 223 & 48.6 & 220 & 239 & 52.1 \\
\hline $\mathrm{OH}$ & 12 & 10 & 45.5 & 11 & 11 & 50.0 \\
\hline TX & 32 & 16 & 33.3 & 27 & 21 & 43.8 \\
\hline Bankruptcy court & 19 & 4 & 17.4 & 17 & 6 & 26.1 \\
\hline No forum specified & 1607 & 110 & 6.4 & 1435 & 282 & 16.4 \\
\hline Other & 146 & 57 & 28.1 & 119 & 84 & 41.4 \\
\hline Foreign forum & 41 & 3 & 6.8 & 34 & 10 & 22.7 \\
\hline Total & 2,256 & 560 & 19.9 & 2,002 & 814 & 28.9 \\
\hline
\end{tabular}

Source: SEC EDGAR database, LEXIS EDGAR PLUS database, January 2002 to June 30, 2002 for all contract types other than mergers and January 2002 to July 31, 2002 for merger contracts. The first three numerical columns treat contracts with arbitration clauses no differently than other contracts. The second set of three numerical columns treats arbitration clauses as jury trial waivers.

percent. Contracts that do not specify a forum have a waiver rate of only 6.4 percent. Thus, over 90 percent of lawyers who do not specify a forum do not include jury trial waiver clauses. They are, in a sense, opting in to the court system in all its glory with possible jury or bench trials. This dominant pattern-no forum choice and no jury trial waiver-accounts for 1,607 of 2,816 contracts. A second group of lawyers and parties wants to control the forum but also wishes to preserve access to a jury trial: they designate a forum but do not waive juries. Except for those contracts specifying Illinois as a forum, more than half the contracts that specify a choice of forum do not opt out of jury trials. This group accounts for 649 contracts. The difference in jury trial waiver rates between those contracts that specify a forum and those that do not is highly statistically significant $(p<0.001)$.

A third group of lawyers and parties wants to specify the forum, and avoid juries, but preserve access to judges: they designate a forum and waive jury trials. This group accounts for 450 contracts. A fourth, small group, consisting of 110 contracts, does not specify a forum but does waive jury trials. Thus the vast majority that do not specify a forum fully opt into the 
legal system by preserving access to jury trials. A fifth group of contracts opts out of the court system altogether by including a contractual arbitration clause. Table 3's second set of three columns shows that this occurs in about 9 percent of the contracts. One could appropriately reduce the number of members in the first four groups to reflect those opting out of the system.

Two of the forum choices in Table 3, though infrequent, merit additional comment. Twenty-three contracts specified bankruptcy courts as the forum, presumably because one or more of the parties was involved in a bankruptcy proceeding as debtor or creditor. In 1994, Congress amended Title 28 to resolve doubt about bankruptcy courts' authority to conduct jury trials. If a right to a jury trial applies to a matter that may be heard by a bankruptcy judge, the judge "may conduct the jury trial if specially designated to exercise such jurisdiction by the district court and with the express consent of all the parties." 36 The consent requirement does not necessarily mean that a contract specifying a bankruptcy court forum thereby assures avoidance of a jury trial. A proper jury demand may result in the withdrawal of the case from the bankruptcy court and adjudication by a federal district court. ${ }^{37}$ It therefore is appropriate to include in the analysis contracts specifying a bankruptcy court forum.

An additional 44 contracts specified a foreign forum. Jury trials in civil cases outside the United States are uncommon and one might not expect such contracts to waive jury trial because doing so would be unnecessary. However, contracts specifying a foreign forum do not conclusively determine the forum because courts may not respect the choice. Expressly waiving jury trial would further reduce the risk of a jury trial and the absence of a waiver therefore can be important. In any event, including these few foreign-forum contracts does not materially affect the results.

\section{Contract Choice of Law}

As in the case of choice of forum, jury trial waivers may vary with choice of law. Because choice of law is concentrated in three states, we report the rates of jury trial waiver for four choices of law: Delaware, New York, California,

\footnotetext{
3628. U.S.C. § $157(\mathrm{e})$.

${ }^{37}$ E.g., Michaelesco v. Shefts, 303 B.R. 249 (D. Conn. 2004). Under 28 U.S.C. $\$ 157$ (d), a district court may withdraw cases from the bankruptcy court for cause. The presence of a jury demand can influence the cause determination. In re Orion Pictures Corp. v. Showtime Networks, 4 F.3d 1095, 1101 (2d Cir. 1993); In re Kenai Corp. v. National Union Fire Ins. Co., 136 B.R. 59, 61 (S.D.N.Y. 1992).
} 
Table 4: Jury Trial Waiver Rates and Contract Choice of Law

\begin{tabular}{|c|c|c|c|c|c|c|}
\hline \multirow[b]{2}{*}{ Choice of Law } & \multicolumn{3}{|c|}{$\begin{array}{c}\text { No Separate Treatment of Contracts } \\
\text { with Arbitration Clauses }\end{array}$} & \multicolumn{3}{|c|}{$\begin{array}{l}\text { Arbitration Clauses Treated } \\
\text { as Jury Trial Waivers }\end{array}$} \\
\hline & $\begin{array}{l}\text { N No Jury } \\
\text { Trial Waiver }\end{array}$ & $\begin{array}{l}\mathrm{N} \text { Jury } \\
\text { Trial Waiver }\end{array}$ & $\begin{array}{l}\text { Rate } \\
(\%)\end{array}$ & $\begin{array}{l}\text { N No Jury } \\
\text { Trial Waiver }\end{array}$ & $\begin{array}{l}\text { N Jury } \\
\text { Trial Waiver }\end{array}$ & $\begin{array}{l}\text { Rate } \\
(\%)\end{array}$ \\
\hline $\mathrm{DE}$ & 289 & 90 & 23.7 & 245 & 134 & 35.4 \\
\hline NY & 1047 & 255 & 19.6 & 1002 & 300 & 23.0 \\
\hline $\mathrm{CA}$ & 175 & 44 & 20.1 & 136 & 83 & 37.9 \\
\hline Other & 659 & 165 & 20.0 & 546 & 278 & 33.7 \\
\hline Total & 2,170 & 554 & 20.3 & 1,929 & 795 & 29.2 \\
\hline
\end{tabular}

Source: SEC EDGAR database, LEXIS EDGAR PLUS database, January 2002 to June 30, 2002 for all contract types other than mergers and January 2002 to July 31, 2002 for merger contracts. The first three numerical columns treat contracts with arbitration clauses no differently than other contracts. The second set of three numerical columns treats arbitration clauses as jury trial waivers.

and Other. ${ }^{38}$ Table 4 shows the rate of jury trial waivers for these four choices.

Unlike choice of forum, virtually every contract specifies a choice of law. And, unlike forum variation, little variation exists in jury trial waiver rates across choices of law. Table 4's first three numerical columns show that the jury trial waiver rate varies by about 4 percent, with 23.7 percent of contracts specifying Delaware law waiving jury trial compared to 19.6 percent of contracts specifying New York law. The waiver rates do not differ significantly across the four groups $(p=0.357)$. Greater and statistically significant variation exists if one regards arbitration clauses as jury trial waivers, as shown in the table's last three columns. Much of this variation is attributable to New York's low rate of arbitration clauses. ${ }^{39}$

\section{B. Party-Specific Factors}

\section{International Contracts Compared to Domestic Contracts}

Prior research suggests that foreigners may fear domestic U.S. courts and, in particular, U.S. juries, more than domestic parties do and therefore may fear

\footnotetext{
${ }^{38}$ For contracts that designate more than one state's law (e.g., New York law governs except where Delaware law applies), we use the first-mentioned state.

${ }^{39}$ See Eisenberg \& Miller, Arbitration, supra note 16.
} 
Table 5: Summary of Jury Trial Waiver Clauses by Party Status

\begin{tabular}{|c|c|c|c|c|c|}
\hline & \multicolumn{2}{|c|}{$\begin{array}{l}\text { No Separate Treatment } \\
\text { of Contracts with } \\
\text { Arbitration Clauses }\end{array}$} & \multicolumn{2}{|c|}{$\begin{array}{c}\text { Arbitration Clauses } \\
\text { Treated as Jury } \\
\text { Trial Waivers }\end{array}$} & \multirow[b]{3}{*}{ Total } \\
\hline & 1 & 2 & 3 & 4 & \\
\hline & $\begin{array}{c}\text { No Jury } \\
\text { Trial Waiver }\end{array}$ & $\begin{array}{c}\text { Jury Trial } \\
\text { Waiver }\end{array}$ & $\begin{array}{c}\text { No Jury } \\
\text { Trial Waiver }\end{array}$ & $\begin{array}{c}\text { Jury Trial } \\
\text { Waiver }\end{array}$ & \\
\hline $\begin{array}{c}\text { No non-U.S. } \\
\text { party }(N)\end{array}$ & 2,034 & 507 & 1,829 & 706 & $2,541 / 2,535$ \\
\hline Percent & 80.1 & 20.0 & 72.2 & 27.9 & 100.0 \\
\hline $\begin{array}{l}\text { Non-U.S. } \\
\text { party }(N)\end{array}$ & 219 & 53 & 166 & 106 & 270 \\
\hline Percent & 80.5 & 19.5 & 61.0 & 39.0 & 100.0 \\
\hline Total $(N)$ & 2,253 & 560 & 1,995 & 812 & $2,813 / 2,807$ \\
\hline Percent & 80.1 & 19.9 & 71.1 & 28.9 & 100.0 \\
\hline
\end{tabular}

$p=0.936$ for Columns 1 and 2; $p<0.001$ for Columns 3 and 4 .

SoURCE: SEC EDGAR database, LEXIS EDGAR PLUS database, January 2002 to June 30, 2002 for all contract types other than mergers and January 2002 to July 31, 2002 for merger contracts. Variation in "Total" column is due to missing values. Columns 3 and 4 treat arbitration clauses as jury trial waivers. Contracts in which either party is a non-U.S. entry are coded as non-U.S. party contracts. Row percents may exceed 100.0 due to rounding.

juries more than do domestic parties. ${ }^{40}$ Table 5 reports the rates at which domestic and international contracts have jury trial waivers. Columns 1 and 2 include contracts with arbitration clauses without characterizing all arbitration clauses as jury trial waivers. About 20 percent of both domestic and international contracts waive jury trials. The difference is not statistically significant.

Columns 3 and 4 of Table 5 characterize arbitration clauses as jury trial waivers. Treating arbitration clauses as jury waivers therefore affects international contracts more than domestic contracts. Column 4 shows that 39 percent of international contracts then contain waivers compared to about 28 percent of domestic contracts. The result is statistically significant at $p<0.001$.

\footnotetext{
${ }^{40}$ Clermont \& Eisenberg, Xenophilia, supra note 19, at 1120 (quoting statement that Japanese litigants cannot get a fair trial because of anti-Japanese bias among U.S. jurors). As reported in previous work, arbitration clauses are significantly more common for international contracts, although still infrequent in absolute terms. Eisenberg \& Miller, Arbitration, supra note 16.
} 
Table 6: Place of Business Assigned to Each Contract Type

\begin{tabular}{ll}
\hline Contract Type & \multicolumn{1}{c}{ Place of Business Used } \\
\hline Asset sale purchase & Buyer's place of notice location \\
Bond indentures & Issuer's place of business \\
Credit commitments & Principal lender's designated office \\
Employment contracts & Employer's place of business \\
Licensing & Licensor's place of business \\
Mergers & Acquiring company's place of business \\
Pooling and servicing & Depositor's place of business \\
Securities purchase & Issuer's place of business \\
Security agreements & Registrant's place of business \\
Settlements & Reporting company's place of business \\
Underwriting & Issuer's place of business \\
\hline
\end{tabular}

Source: SEC EDGAR database, LEXIS EDGAR PLUS database, January 2002 to June 30, 2002 for all contract types other than mergers and January 2002 to July 31, 2002 for merger contracts. Excludes contracts categorized as "Other."

\section{Place of Business}

We code business location at the state level. Designating a single business locale per contract requires considering the nature of the contract. ${ }^{41}$ For some types of contract, such as merger, two places of business are plausiblethe acquiring company's and the acquired company's. For such contracts, we used what one might expect would normally be the dominant place of business. For example, for merger contracts, we use the acquiring company's place of business. Table 6 shows the business locale chosen for 11 types of contracts. Because of the varied nature of the contract category "Other," we exclude such contracts from this analysis.

Table 7 shows the jury waiver pattern by place of business. Places of business are more diffuse than choices of law so we report results for more states in the analysis. Like the previous tables, Table 7 reports the rate of express jury trial waivers and the rate of jury trial waivers if one equates arbitration clauses with jury trial waivers. The rates of jury trial waiver vary from zero for contracts associated with Michigan to 44.4 percent for con-

\footnotetext{
${ }^{41}$ One could employ models that include two business locales for a contract. E.g., Eisenberg \& Miller, Arbitration, supra note 16 (considering acquired and acquiring companies locales in study of mergers). However, the instant analysis already accounts for several geographical dimensions-choice of forum, choice of law, place of dominant contracting party's business, incorporation, and attorney locale. The marginal contribution of a second place of business or incorporation is likely to be small.
} 
Table 7: Jury Trial Waiver Rates and Place of Business

\begin{tabular}{|c|c|c|c|c|c|c|}
\hline \multirow[b]{2}{*}{$\begin{array}{l}\text { Place of } \\
\text { Business }\end{array}$} & \multicolumn{3}{|c|}{$\begin{array}{l}\text { No Separate Treatment of } \\
\text { Contracts with Arbitration Clauses }\end{array}$} & \multicolumn{3}{|c|}{$\begin{array}{l}\text { Arbitration Clauses Treated } \\
\text { as Jury Trial Waivers }\end{array}$} \\
\hline & $\begin{array}{l}\text { N No Jury } \\
\text { Trial Waiver }\end{array}$ & $\begin{array}{l}\text { N Jury } \\
\text { Trial Waiver }\end{array}$ & $\begin{array}{l}\text { Rate } \\
(\%)\end{array}$ & $\begin{array}{l}\text { N No Jury } \\
\text { Trial Waiver }\end{array}$ & $\begin{array}{l}\text { N Jury } \\
\text { Trial Waiver }\end{array}$ & $\begin{array}{l}\text { Rate } \\
(\%)\end{array}$ \\
\hline $\mathrm{AZ}$ & 31 & 1 & 3.1 & 24 & 8 & 25.0 \\
\hline CA & 293 & 82 & 21.9 & 246 & 129 & 34.4 \\
\hline CAN & 34 & 5 & 12.8 & 27 & 12 & 30.8 \\
\hline $\mathrm{CO}$ & 45 & 7 & 13.5 & 38 & 14 & 26.9 \\
\hline CT & 36 & 8 & 18.2 & 34 & 10 & 22.7 \\
\hline $\mathrm{DC}$ & 11 & 1 & 8.3 & 10 & 2 & 16.7 \\
\hline $\mathrm{DE}$ & 26 & 7 & 21.2 & 26 & 7 & 21.2 \\
\hline FL & 85 & 27 & 24.1 & 75 & 37 & 33.0 \\
\hline GA & 31 & 11 & 26.2 & 28 & 14 & 33.3 \\
\hline IL & 66 & 26 & 28.3 & 64 & 28 & 30.4 \\
\hline LA & 19 & 2 & 9.5 & 14 & 7 & 33.3 \\
\hline MA & 48 & 26 & 35.1 & 45 & 29 & 39.2 \\
\hline MD & 36 & 11 & 23.4 & 35 & 12 & 25.5 \\
\hline MI & 20 & 0 & 0.0 & 19 & 1 & 5.0 \\
\hline $\mathrm{MN}$ & 50 & 10 & 16.7 & 47 & 13 & 21.7 \\
\hline MO & 19 & 6 & 24.0 & 17 & 8 & 32.0 \\
\hline $\mathrm{NC}$ & 40 & 11 & 21.6 & 36 & 15 & 29.4 \\
\hline $\mathrm{NH}$ & 10 & 2 & 16.7 & 9 & 3 & 25.0 \\
\hline NJ & 63 & 17 & 21.3 & 55 & 25 & 31.3 \\
\hline NV & 37 & 2 & 5.1 & 36 & 3 & 7.7 \\
\hline $\mathrm{NY}$ & 208 & 75 & 26.5 & 187 & 96 & 33.9 \\
\hline $\mathrm{OH}$ & 29 & 10 & 25.6 & 27 & 12 & 30.8 \\
\hline OR & 10 & 8 & 44.4 & 8 & 10 & 55.6 \\
\hline PA & 67 & 9 & 11.8 & 52 & 24 & 31.6 \\
\hline TX & 169 & 42 & 19.9 & 153 & 58 & 27.5 \\
\hline UT & 27 & 4 & 12.9 & 22 & 9 & 29.0 \\
\hline VA & 51 & 5 & 8.9 & 50 & 6 & 10.7 \\
\hline WA & 38 & 3 & 7.3 & 29 & 12 & 29.3 \\
\hline Other & 272 & 63 & 18.8 & 232 & 103 & 30.7 \\
\hline Total & 1,871 & 481 & 20.5 & 1,645 & 707 & 30.1 \\
\hline
\end{tabular}

Source: SEC EDGAR database, LEXIS EDGAR PLUS database, January 2002 to June 30,2002 for all contract types other than mergers and January 2002 to July 31, 2002 for merger contracts. Excludes contracts categorized as "Other." Place of business is assigned to a single state as described in Table 6.

tracts associated with Oregon. This variation persists if one equates arbitration clauses with jury trial waivers, but both states have relatively few contracts associated with them.

For the states with many contracts-California, Florida, New York, and Texas each have more than 100 contracts-waiver rates are relatively stable. 
Table 8: Jury Trial Waiver Rates and Place of Incorporation

\begin{tabular}{|c|c|c|c|c|c|c|}
\hline \multirow[b]{2}{*}{$\begin{array}{l}\text { Place of } \\
\text { Incorporation }\end{array}$} & \multicolumn{3}{|c|}{$\begin{array}{l}\text { No Separate Treatment of } \\
\text { Contracts with Arbitration Clauses }\end{array}$} & \multicolumn{3}{|c|}{$\begin{array}{c}\text { Arbitration Clauses Treated } \\
\text { as Jury Trial Waivers }\end{array}$} \\
\hline & $\begin{array}{l}\text { N No Jury } \\
\text { Trial Waiver }\end{array}$ & $\begin{array}{l}\mathrm{N} \text { Jury } \\
\text { Trial Waiver }\end{array}$ & $\begin{array}{l}\text { Rate } \\
(\%)\end{array}$ & $\begin{array}{l}\mathrm{N} \text { No Jury } \\
\text { Trial Waiver }\end{array}$ & $\begin{array}{l}\mathrm{N} \text { Jury } \\
\text { Trial Waiver }\end{array}$ & $\begin{array}{l}\text { Rate } \\
(\%)\end{array}$ \\
\hline CA & 74 & 12 & 14.0 & 61 & 25 & 29.1 \\
\hline $\mathrm{DE}$ & 916 & 194 & 17.5 & 822 & 288 & 25.9 \\
\hline FL & 46 & 12 & 20.7 & 38 & 20 & 34.5 \\
\hline MD & 73 & 14 & 16.1 & 71 & 16 & 18.4 \\
\hline NV & 129 & 18 & 12.2 & 105 & 42 & 28.6 \\
\hline NY & 49 & 25 & 33.8 & 47 & 27 & 36.5 \\
\hline Other & 584 & 206 & 26.1 & 501 & 289 & 36.6 \\
\hline Total & 1,871 & 481 & 20.5 & 1,645 & 707 & 30.1 \\
\hline
\end{tabular}

Source: SEC EDGAR database, LEXIS EDGAR PLUS database, January 2002 to June 30, 2002 for all contract types other than mergers and January 2002 to July 31, 2002 for merger contracts. Excludes contracts categorized as "Other." Separately reports only states with at least 50 contracts with the key contracting party being incorporated in the state.

For these states, the jury trial waiver rates vary from 26.5 percent in New York to 19.9 percent in Texas. These two extremes do not significantly differ $(p=0.108)$. If one equates arbitration clauses with waivers, the waiver rate ranges from 34.4 percent in California to 27.5 percent in Texas. That difference is marginally statistically significant $(p=0.097)$.

\section{Place of Incorporation}

For some types of contract, such as merger, two places of incorporation are plausible-the acquiring company's and the acquired company's (but often both are Delaware). Place of incorporation for a contract is assigned using the same criteria as was used for place of business above. For example, in merger contracts, the acquiring company's place of incorporation is used.

Table 8 reports the proportion of contracts with jury trial waiver clauses. To keep the output manageable and focus on the states with the most incorporations, we separately report results for the six states with at least 50 contracts with a contracting party being incorporated in the state. States with fewer such contracts are included in the residual category, "Other."

The table confirms that Delaware dominates in incorporations. Variation in place of incorporation can therefore only contribute modestly to explaining the overall pattern of jury trial waivers. However, variation does 
Table 9: Jury Trial Waiver Rates and Attorney Locale

\begin{tabular}{|c|c|c|c|c|c|c|}
\hline \multirow[b]{2}{*}{$\begin{array}{l}\text { Attorney } \\
\text { Locale }\end{array}$} & \multicolumn{3}{|c|}{$\begin{array}{l}\text { No Separate Treatment of } \\
\text { Contracts with Arbitration Clauses }\end{array}$} & \multicolumn{3}{|c|}{$\begin{array}{l}\text { Arbitration Clauses Treated } \\
\text { as Jury Trial Waivers }\end{array}$} \\
\hline & $\begin{array}{l}\text { N No Jury } \\
\text { Trial Waiver }\end{array}$ & $\begin{array}{l}\text { N Jury } \\
\text { Trial Waiver }\end{array}$ & Rate & $\begin{array}{l}\text { N No Jury } \\
\text { Trial Waiver }\end{array}$ & $\begin{array}{l}\text { N Jury } \\
\text { Trial Waiver }\end{array}$ & $\begin{array}{l}\text { Rate } \\
(\%)\end{array}$ \\
\hline CA & 119 & 63 & 34.6 & 98 & 84 & 46.2 \\
\hline IL & 34 & 17 & 33.3 & 30 & 21 & 41.2 \\
\hline MA & 33 & 22 & 40.0 & 25 & 30 & 54.5 \\
\hline NY & 197 & 72 & 26.8 & 180 & 89 & 33.1 \\
\hline PA & 43 & 7 & 14.0 & 36 & 14 & 28.0 \\
\hline TX & 66 & 24 & 26.7 & 59 & 31 & 34.4 \\
\hline Other & 1379 & 276 & 16.7 & 1217 & 438 & 26.5 \\
\hline Total & 1,871 & 481 & 20.5 & 1,645 & 707 & 30.1 \\
\hline
\end{tabular}

Source: SEC EDGAR database, LEXIS EDGAR PLUS database, January 2002 to June 30, 2002 for all contract types other than mergers and January 2002 to July 31, 2002 for merger contracts. Excludes contracts categorized as "Other." Separately reports only states with at least 50 contracts indicating the state is an attorney's locale.

exist, with waiver rates varying from 12.2 percent in Nevada to 33.8 percent for those contracts with companies incorporated in New York. The differences in both sections of the table are highly statistically significant $(p<0.001)$.

\section{Attorney Place of Business}

Information about attorney locale is sketchier than is information about the other geographic factors. Attorney locale is available only for law firms mentioned in the Form 8-K with useable addresses. And we could not always link an attorney mentioned with a principal party to the contract.

Table 9 reports attorney locale and the rate of jury trial waiver clauses. It separately reports only states with at least 50 attorney locales. Attorney locale is more dispersed than choice of law. As shown above, Delaware, New York, and California account for almost 70 percent of the choices of law but they account for much less than 50 percent of the attorney locales. Delaware as a locale for attorneys was not extracted from even 50 contracts. Even considering the greater likelihood of missing attorney locale data, New York and California are the leading locales but they constitute a small portion of the contracts. New York can be identified as an attorney locale in 269 contracts and California can be so identified in 182 contracts. The large "Other" locale category precludes determining whether attorney locale is more concentrated than business locale. 
California's 34.6 percent of contracts with jury trial waivers is higher than New York's rate of 26.8 percent, but the difference is only marginally statistically significant $(p=0.076)$. Table 9's last three columns shows that the difference grows $(p=0.006)$ if one regards arbitration clauses as jury trial waivers due to California contracts' greater use of arbitration clauses. The insignificant results for New York attorneys are intriguing given our earlier finding that New York attorneys were significantly more likely than other attorneys to include choice of forum provisions in merger contracts, ${ }^{42}$ thus suggesting that they pay close attention to ex ante dispute resolution considerations. However, such attention does not extend to waiving jury trials at a significantly above-average rate. ${ }^{43}$

\section{Industry Groups}

We hypothesized that jury trial waiver may vary by industry. A reporting company's SEC filing includes its Standard Industry Classification (SIC), which consists of a four-digit SIC code. ${ }^{44}$ The SIC system used in SEC filings yields many industry categories that contain too few firms to allow for reasonable statistical analysis. We therefore regroup the SIC categories into 17 reasonably sized classifications. ${ }^{45}$

Table 10 reports the rate of jury trial waiver clauses by these classifications. Waiver clause use varies by industry. The table as a whole yields

\footnotetext{
${ }^{42}$ Eisenberg \& Miller, Arbitration, supra note 16.

${ }^{43}$ Note also the prominence of merger contracts and attorney locale in the branch of Figure 5's classification tree when a contract does not specify a forum. Merger contracts are the highest node under the no-forum-specified node and attorney locale is the highest node under merger contracts.

Table 9 also suggests that Illinois attorneys are not associated with an unusually high rate of jury trial waivers. Yet Table 3 suggests that Illinois as a choice of forum is associated with a high waiver rate. The high waiver rate associated with Illinois as a choice of forum may result from waivers by non-Illinois attorneys who designate Illinois as a forum. However, this result is tentative because of the many contracts without attorney locale information.

${ }^{44}$ See $\langle$ http://www.sec.gov/info/edgar/siccodes.htm〉.

${ }^{45}$ The 28 industry groups used in U.S. General Accounting Office, Public Accounting Firms: Mandated Study on Consolidation and Competition, GAO-3-864, at 111 (July 2003), were reduced to the 17 industry groups used in Theodore Eisenberg \& Jonathan R. Macey, Was Arthur Andersen Different?: An Empirical Examination of Major Accounting Firms' Audits of Large Clients, 1 J. Empirical Legal Stud. 263 (2004).
} 
Table 10: Jury Trial Waiver Rates and Industry

\begin{tabular}{|c|c|c|c|c|c|c|}
\hline \multirow[b]{2}{*}{ Major Industry Groups } & \multicolumn{3}{|c|}{$\begin{array}{l}\text { No Separate Treatment of } \\
\text { Contracts with Arbitration Clauses }\end{array}$} & \multicolumn{3}{|c|}{$\begin{array}{l}\text { Arbitration Clauses Treated } \\
\text { as Jury Trial Waivers }\end{array}$} \\
\hline & $\begin{array}{l}\text { N No Jury } \\
\text { Trial Waiver }\end{array}$ & $\begin{array}{l}\mathrm{N} \text { Jury } \\
\text { Trial Waiver }\end{array}$ & $\begin{array}{l}\text { Rate } \\
(\%)\end{array}$ & $\begin{array}{l}\text { N No Jury } \\
\text { Trial Waiver }\end{array}$ & $\begin{array}{l}\mathrm{N} \text { Jury } \\
\text { Trial Waiver }\end{array}$ & $\begin{array}{l}\text { Rate } \\
(\%)\end{array}$ \\
\hline Mineral industries & 83 & 18 & 17.8 & 72 & 29 & 28.7 \\
\hline Construction industries & 19 & 7 & 26.9 & 16 & 10 & 38.5 \\
\hline Manufacturing & 119 & 41 & 25.6 & 105 & 55 & 34.4 \\
\hline $\begin{array}{l}\text { Transportation \& } \\
\text { utilities }\end{array}$ & 94 & 12 & 11.3 & 91 & 15 & 14.2 \\
\hline Communications & 82 & 25 & 23.4 & 76 & 31 & 29.0 \\
\hline Wholesale trade & 57 & 28 & 32.9 & 50 & 35 & 41.2 \\
\hline Retail trade & 69 & 28 & 28.9 & 59 & 38 & 39.2 \\
\hline $\begin{array}{l}\text { Finance, insurance, } \\
\text { real estate }\end{array}$ & 673 & 86 & 11.3 & 647 & 112 & 14.8 \\
\hline Services & 405 & 149 & 26.9 & 333 & 221 & 39.9 \\
\hline $\begin{array}{l}\text { Instruments \& related } \\
\text { products }\end{array}$ & 50 & 18 & 26.5 & 43 & 25 & 36.8 \\
\hline $\begin{array}{l}\text { Food \& kindred } \\
\text { products, agriculture, } \\
\text { forest, fishing }\end{array}$ & 24 & 10 & 29.4 & 23 & 11 & 32.4 \\
\hline Paper \& allied products & 18 & 3 & 14.3 & 16 & 5 & 23.8 \\
\hline $\begin{array}{l}\text { Chemicals \& allied } \\
\text { products }\end{array}$ & 123 & 33 & 21.2 & 102 & 54 & 34.6 \\
\hline $\begin{array}{l}\text { Industrial machinery \& } \\
\text { equip. }\end{array}$ & 78 & 23 & 22.8 & 58 & 43 & 42.6 \\
\hline $\begin{array}{l}\text { Electrical \& electronic } \\
\text { equip. }\end{array}$ & 87 & 43 & 33.1 & 70 & 60 & 46.2 \\
\hline Transportation equip. & 23 & 5 & 17.9 & 19 & 9 & 32.1 \\
\hline $\begin{array}{l}\text { No SIC listed or SIC } \\
\text { missing }\end{array}$ & 252 & 31 & 11.0 & 222 & 61 & 21.6 \\
\hline Total & 2,256 & 560 & 19.9 & 2,002 & 814 & 28.9 \\
\hline
\end{tabular}

Source: SEC EDGAR database, LEXIS EDGAR PLUS database, January 2002 to June 30, 2002 for all contract types other than mergers and January 2002 to July 31, 2002 for merger contracts.

statistically significant interindustry differences $(p<0.001)$. The "finance, insurance, real estate" grouping is the largest, accounting for over onequarter of the contracts, and has a low rate (11.3 percent) of jury trial waiver clauses. The "transportation and utilities" industry has the same low rate. The highest rate of jury trial waiver clauses, 33.1 percent, is in the "electrical and electronic equipment" grouping. Comparing Table 10 to Table 2 indicates that the range of jury trial waiver rates is much smaller across industry (11.3 to 33.1 percent) than it is across contract type (1.9 to 64.5 percent). 
Industry practice thus appears to be less of a driving force on trial jury waiver rates than is the kind of contract.

\section{Jury-Trial-Related Factors External to the Parties or the Contract}

Jury-related factors external to the contracts and parties should influence jury trial waiver rates. The contract types and the parties do not change their inherent characteristics as the result of jury-related considerations. In contrast, jury-related factors external to the parties and contracts may directly influence parties considering jury trial waivers. Parties who perceive juries to be unfair should waive jury trials regardless of party or contract characteristics. The parties can retain their choice of law, choice of forum, and other salient contract terms without subjecting themselves to a possibly unfair adjudicator. Similarly, parties who believe jury trials to be relatively costly and inefficient can avoid juries without altering other contract characteristics.

\section{Perceived Fairness of States' Juries}

One measure of whether perceptions of juries are associated with the rate of jury trial waivers is whether states perceived to have the least fair juries have the highest rates of jury trial waiver clauses. Figure 3 shows the relation between a state's rate of jury trial waiver clauses and large corporations', as surveyed by the Chamber of Commerce, ${ }^{46}$ perceptions of states' jury fairness. ${ }^{47}$ We associate states with contracts based on the contractual term that most directly addresses the potential jury pool, the choice of forum.

If a positive association exists between jury fairness perceptions and jury trial waiver rates, the figure's data points should flow from lower left to upper right. The lower left of the figure, near the origin, corresponds with high, favorable rankings in perceived jury fairness and low jury waiver rates. The upper right corresponds with low rankings in perceived jury fairness and high-ranking jury trial waiver clause rates. The expected relation is observed.

\footnotetext{
${ }^{46}$ E.g., U.S. Chamber of Commerce, supra note 26. The Chamber and other business groups use the Chamber's ranking studies to try to influence courts to restrict causes of action and constrain legal actions against the business community. E.g., Brief of Chamber of Commerce of the United States, 2004 WL 2125702, Henry v. Dow Chem. Co., 701 N.W.2d 684 (Mich. 2005); Amicus Curiae Brief of Wis. Mfrs. \& Commerce, 2002 WL 32699975, Wischer v. Mitsubishi Heavy Inds. Am., Inc., 673 N.W.2d 303 (Wis. App. 2002). We use the 2002 Chamber Report because it corresponds to the year of our contracts.
}

${ }^{47}$ Chamber of Commerce, supra note 26, at 28 (tbl. 15 Juries' Fairness). 
Figure 3: Jury waiver clause rank and jury fairness rank.

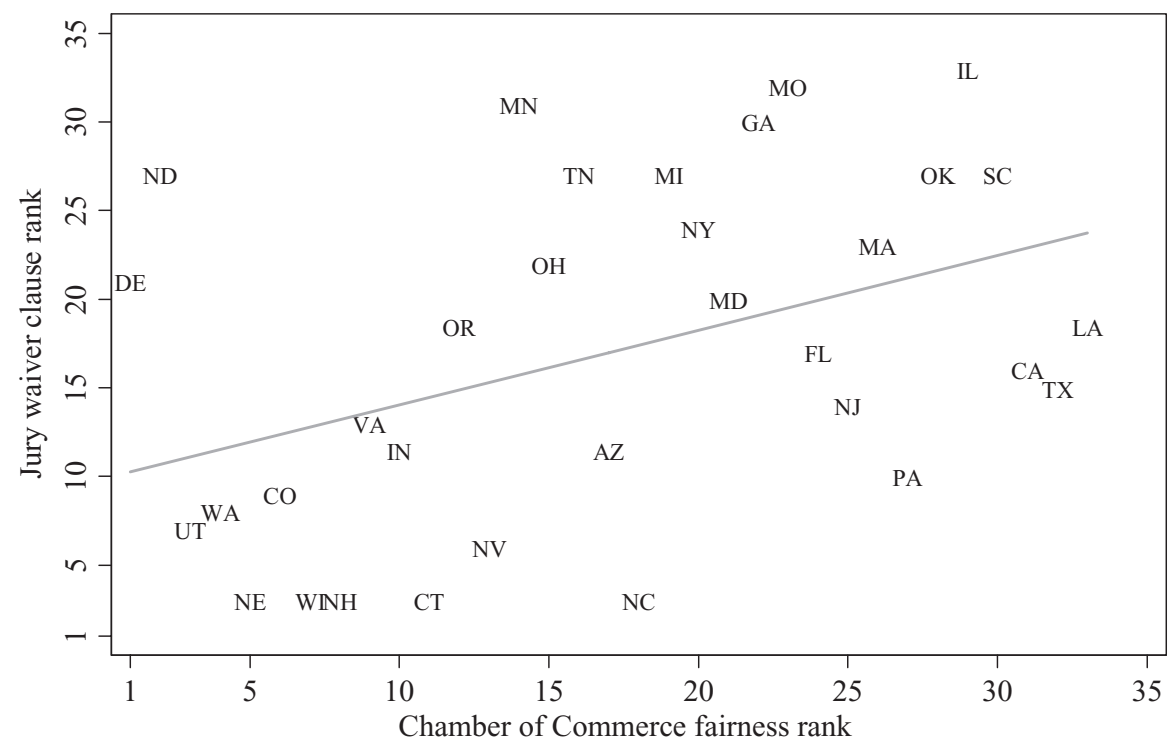

Sources: U.S. Chamber of Commerce State Liability Systems Ranking Study, Final Report, January 11, 2002 (Study No. 14966); SEC EDGAR database, LEXIS EDGAR PLUS database, January 2002 to June 30, 2002 for all contract types other than mergers and January 2002 to July 31, 2002 for merger contracts. Low numerical rankings in the Chamber's system correspond to more fairly ranked jury trial systems. We include states specified as a forum in at least two contracts. The Chamber ranking for the remaining states is not included and the 33 included states were reranked from 1 to 33 . Ties in rank are not broken.

Figure 3 shows a reasonably strong association between perceived jury fairness and jury trial waivers. A measure of the linear correlation, as represented by the straight line in the figure, is statistically significant $(\rho$ (correlation) $=0.42 ; \quad p=0.014){ }^{48}$ Excluding contracts with arbitration clauses from the sample or counting them as jury trial waivers does not materially change the results.

\footnotetext{
${ }^{48}$ This result is based on counting each state as an equal observation and using rankings. Using Kenall's tau yields $p=0.022$. Weighting by the number of contracts for each state reduces size and significance of the effect $(\rho($ correlation $)=0.14 ; p$ (significance $)=0.427)$. However, limiting the sample to states with at least five contracts yields a result similar to the unweighted correlation $(\rho=0.36 ; p=0.090)$. Contract-level models that account for both the number of observations and other factors are discussed in Section V.
} 


\section{Difference in Adjudication Time for Judge and Jury Trials}

The second external influence on jury trial waivers considered is the relative length of the jury trial and bench trial queues in a state. We assess the time on the docket for jury and bench trials using trial data from the Civil Justice Survey of State Courts, a project of the National Center for State Courts and the Bureau of Justice Statistics (BJS). The data come directly from state court clerks' offices and include information on judge and jury trials for all tort, contract, and property trials completed in 2001 in a random sample of 46 of the 75 most populous counties in the United States. ${ }^{49}$

Data limitations allow only partially exploring the waiver-trial queue relation. The BJS sample includes only 16 of the states with a reasonable number of contracts. The data are limited to the counties in the BJS sample and are not a representative statewide sample. Nevertheless, the most populous counties, those used in the BJS study, likely are the dominant choices of forum, places of business, and the like. So these counties are more likely to be the locales for litigation than are smaller counties.

Studying the relation between differences in jury and bench trial queues and jury trial waiver rates requires quantifying each state's difference in time to adjudication for jury and bench trials. Comparing this difference across states requires accounting for the different mixes of case types in the states. If, for example, products liability cases are on the docket longer than promissory note trials, ${ }^{50}$ assessing jury-bench differences across states should account for the different proportions of each state's trial docket that consists of products liability and promissory note cases. We therefore ran a regression model of time on the docket $(\log )$ and extracted from it a measure of the

\footnotetext{
${ }^{49}$ The 75 counties from which the sample was drawn include approximately 33 percent of the 1990 U.S. population; the actual 46 counties contributing data account for approximately 20 percent of the population. For a summary of the data and methodology, see BJS Bulletin, supra note 12. The data include information on trial length in large counties in 16 states: Arizona, California, Connecticut, Florida, Georgia, Illinois, Massachusetts, Minnesota, Missouri, New Jersey, New York, North Carolina, Ohio, Pennsylvania, Texas, and Washington.

${ }^{50}$ Available data indicate that time on the docket differs across case categories. BJS Bulletin, supra note 12, at 8 (products liability tried cases last 35.1 months compared to an overall tort tried case period of 25.6 months; contracts cases take 21.5 months).
} 
Figure 4: Jury trial waiver rate and jury-bench time to adjudication difference.
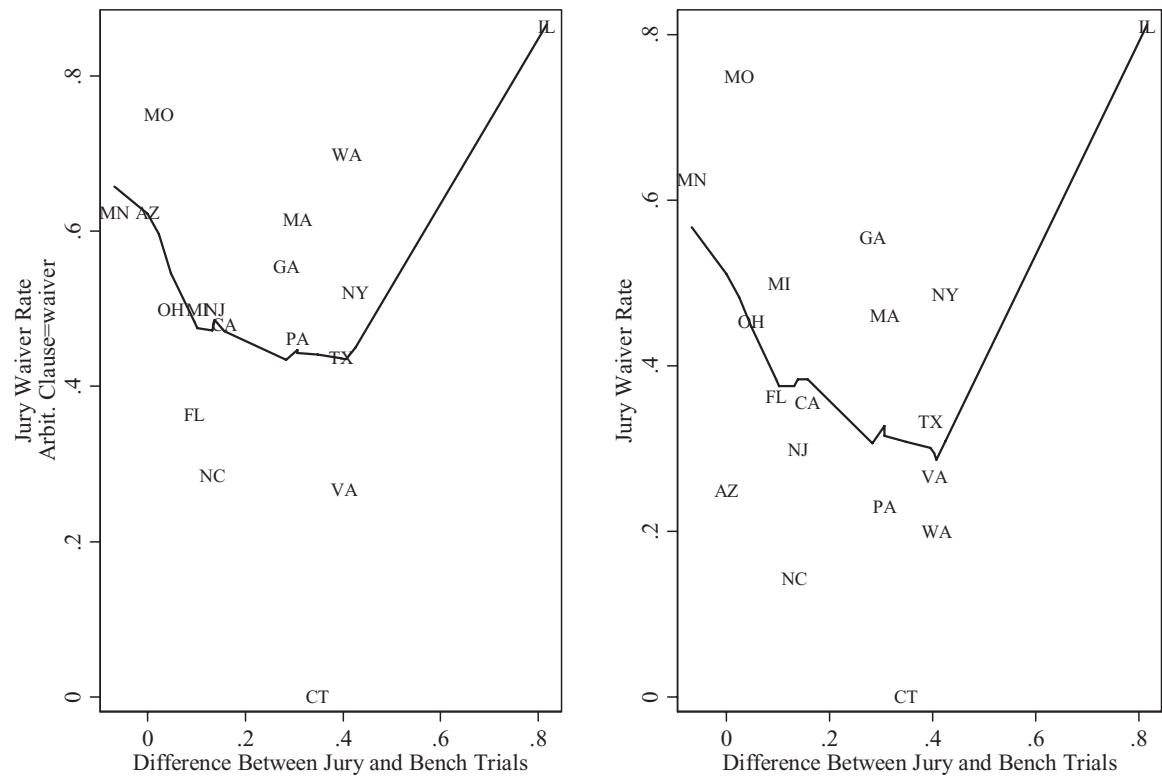

SOURCES: BJS data on trial outcomes in 46 large counties, 2001; SEC EDGAR database, LEXIS EDGAR PLUS database, January 2002 to June 30, 2002 for all contract types other than mergers and January 2002 to July 31, 2002 for merger contracts. The x-axis is a measure, based on regression analysis of the BJS data, of the difference in time to adjudiction between jury and bench trials in a state. The lines are the lowess-smoothed best-fitting values. The y-axis is based on the trial waiver clause data used in this study.

difference between jury and bench trial queues in each locale, after accounting for the case mix. ${ }^{51}$

Figure 4 shows the jury-bench queue difference measure, along the $\mathrm{x}$-axis, and the jury trial waiver rate, measured along the $\mathrm{y}$-axis. The figure uses only contracts containing a choice of forum. Choosing a forum effectively identifies a jury pool and a locale in which to compare the time of jury

\footnotetext{
${ }^{51}$ For the case categories used, see BJS Bulletin, supra note 12. The measure of difference is the regression coefficient on an interaction term consisting of a dummy variable for each state times a dummy variable for jury trials. The regression model included dummy variables for each of the many case categories in the BJS data. The interaction term coefficients are the $\mathrm{x}$-axis values in Figure 4 .
} 
and bench adjudication. ${ }^{52}$ The figure's left side treats arbitration clauses as jury trial waivers. The right side does not treat arbitration clauses separately.

Neither side shows the expected increasing relation. The lines in the figure are the lowess-smoothed best-fitting lines. ${ }^{53}$ No monotonic relation emerges between our measure of jury-bench trial time difference and the rate of jury trial waivers. If anything, most states show an inverse association between jury trial waiver rates and the difference in jury and bench trial time of adjudication. However, this inverse relation does not hold for Illinois. Perhaps the most striking feature of the figure is the large difference between the jury and bench trial times to disposition in Illinois. Chicago litigants ${ }^{54}$ must wait substantially longer, about 16 months, for jury-tried cases to terminate than for judge-tried cases. That difference is about 13 months if one adjusts for the different mix of cases routed to juries and judges.

Assessment of the two external influences on jury trial waivers suggests that perceived jury fairness may help explain the waiver-clause pattern in regression models explored below, but that the trial-queue information will not. We therefore use only the fairness factor in the models.

\section{Regression Models}

Preliminary regression models, not reported here, employed as explanatory variables the most frequently appearing places of business, places of incorporation, and choice of law. These variables were consistently statistically insignificant in models that included what appear to be the variables most strongly associated with jury trial waivers. We therefore focus instead on choice of forum, domestic versus international party status, perceived jury fairness, contract type, and industry classification.

\footnotetext{
${ }^{52}$ One could also reasonably explore the relation between other contract-specific geographic features (place of business, place of incorporation, attorney locale, choice of law) and the rate of jury trial waivers. We expected the link between waiver and geography to be strongest when a forum has been designated.

${ }^{53}$ Lowess smoothing is locally weighted regression of the $y$-variable on the $\mathrm{x}$-variable. Lowess is a desirable smoother because it tends to follow the flow in the data rather than allow remote extreme points to affect a local value. See W.S. Cleveland, The Elements of Graphing Data (1994).

${ }^{54}$ Cook County (Chicago) is the only Illinois county in the BJS data.
} 
The dependent variable in all regression models is a dichotomous variable equal to 1 if a contract contains a jury trial waiver and equal to 0 otherwise. Additional preliminary logistic regression models, also not reported, yielded results largely consistent with Section IV's results except that, inconsistently with Table 3 , there was no significant association between a contract specifying a forum and jury trial being waived. Table 3 suggests that the presence of a litigation forum clause is strongly associated with the presence of a jury trial waiver clause. Only 6.4 percent of the contracts not specifying a choice of forum contain a jury trial waiver clause compared to 40.9 percent of the contracts that do specify a choice of forum. It thus is likely that, for most contracts, a decision is made about whether to specify a forum, and that decision is made simultaneously with, or triggers a related decision about, whether to avoid juries in that forum. A decision not to specify a forum is usually tantamount to not waiving jury trials.

Further inquiry into the relation between forum specification and jury trial waiver was therefore appropriate using methods less subject to the limitations of logistic regression analysis. Figure 5 is a classification and regression tree (CART) of whether jury trial was waived as it relates to the variables of interest. CART analysis helps explore how decisions branch at what are believed to be relevant nodes (the variables). ${ }^{55}$ Each node in a decision tree is split into two groups, and the data are partitioned into those groups to process the data farther down the tree. This binary partitioning process can be repeated, with "child" nodes generating their own subnodes. As seen in Figure 5, each node can be the parent of two nodes and the progenitor of subsequent nodes. CART has the advantage over logistic regression of being nonparametric and therefore not depending on underlying assumptions about the distribution of the explanatory variables.

Figure 5 confirms Table 3's evidence of a strong association between a forum being specified and the presence of a jury trial waiver clause. Specifying a forum is the highest node in the classification tree, suggesting that influences on the decision to waive a trial are subordinate to the forum specification decision. This further supports the common-sense notion that deciding whether to waive a jury trial is not independent of deciding whether to specify a forum. Common factors may affect both decisions but it is implausible that whether to specify a forum is unrelated to whether to waive jury trials.

\footnotetext{
${ }^{55}$ Leo Breiman, Jerome Friedman, Charles J. Stone \& R.A. Olshen, Classification and Regression Trees (1984).
} 


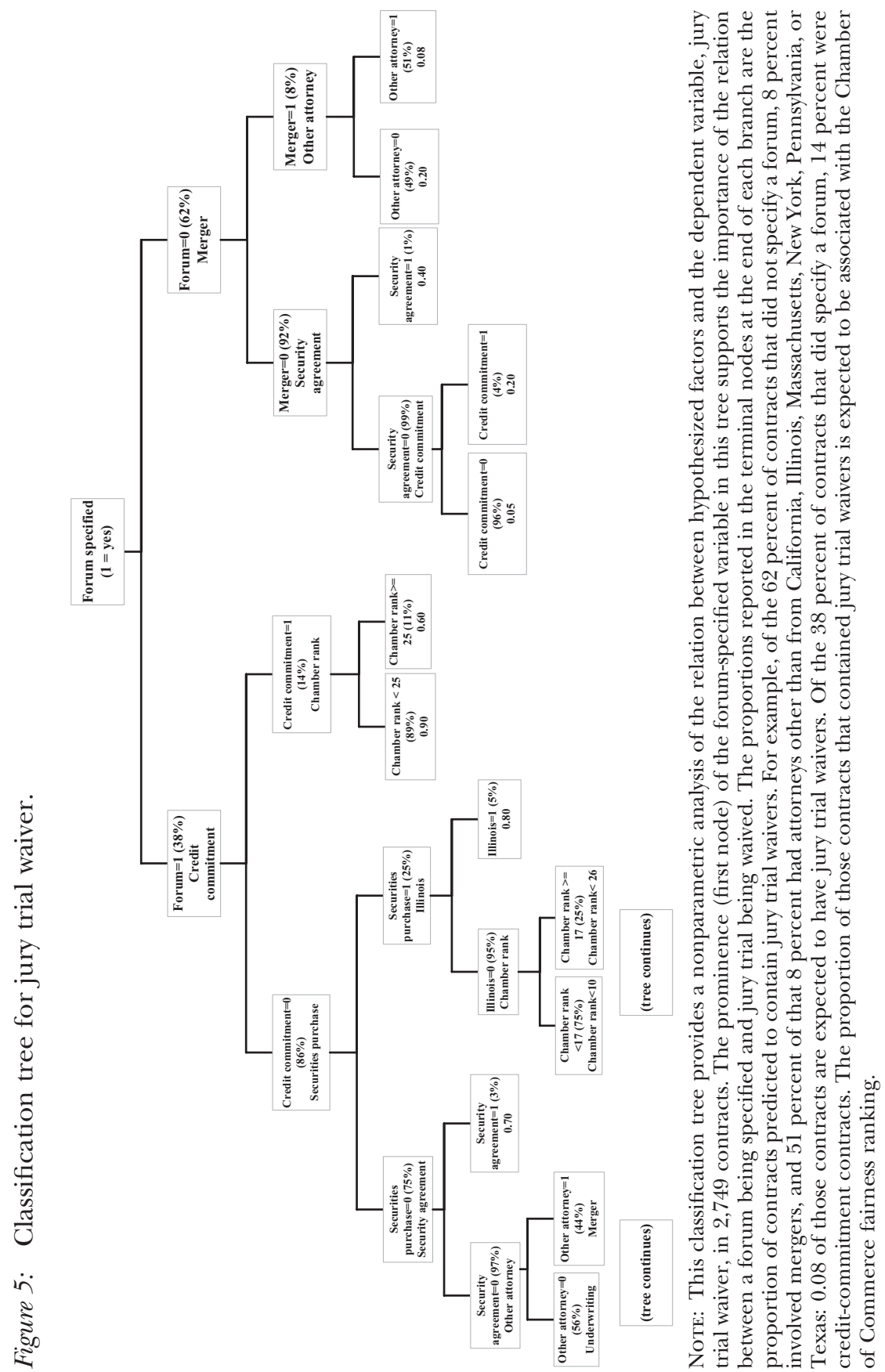


The forum-specification decision, like the waiver-clause decision, is itself likely associated with contract type. For example, 69.2 percent of 211 credit commitment contracts with information about forum specify a forum. That exceeds in rate and number jury trial waivers in credit commitment contracts shown in Table 2. Virtually every security agreement that specifies a forum also waives jury trial. The Appendix shows that, for every contract type other than settlement, a higher fraction of contracts that specify a forum include jury trial waivers than the fraction of contracts that do not specify a forum. Except for a small minority of contracts (the 6.4 percent Table 3 shows to waive jury trial without specifying a forum), the jury trial waivers are from the pool of contracts that designate a forum. The Appendix also shows strong variation in the forum-specification/jury-trial-waiver relation across contract types.

The powerful contract-type effects likely influence the decision to designate a forum as well as the decision to waive a jury trial, as the credit commitment and security agreement numbers suggest. The greater frequency of forum selection than jury trial waiver indicates that waiver clauses are largely conditional on specifying a forum. Thus, the NO FORUM variable in simple logistic regression models likely is not exogenous. It depends on other explanatory variables, at least the contract types. A model of jury trial waiver therefore should account for whether a contract designates a litigation forum. We first model, using probit regression, the decision to include a forum provision in a contract. ${ }^{56}$ The probabilities of a forum selection clause being present, obtained in this preliminary model, are used to generate a variable, employed in probit models of whether a contract includes a jury trial waiver clause, that corrects for the endogeneity of whether a forum is specified. ${ }^{57}$

Table 11 reports the corrected trial waiver probit models. The variable representing whether a forum was specified, NO FORUM, is an explanatory

\footnotetext{
${ }^{56}$ The presence of a forum selection clause was modeled as a function of contract-type dummy variables, a non-U.S. party dummy variable, and attorney locale dummy variables. We include attorney locale variables discussed with respect to Table 9 because previous work showed that New York attorneys specified a forum more frequently than other attorneys in merger contracts. Eisenberg \& Miller, Arbitration, supra note 16. In the forum equations, many contract types are strongly and significantly associated with whether a forum is specified. Most of the forum equations' attorney locale dummy variables are statistically significant from the reference category, "other or unknown attorney locale."

${ }^{57}$ We thank Professor Martin Wells for showing us how to do this correction.
} 
Table 11: Probit Models of Jury Trial Waiver: Dependent Variable $=$ Jury Trial Waiver Present

\begin{tabular}{|c|c|c|c|}
\hline & $\begin{array}{c}1 \\
\text { No Separate } \\
\text { Arbitration Clause } \\
\text { Treatment }\end{array}$ & $\begin{array}{c}2 \\
\text { Arbitration } \\
\text { Clauses Treated } \\
\text { as Waivers }\end{array}$ & $\begin{array}{c}3 \\
\text { No Separate } \\
\text { Arbitration Clause } \\
\text { Treatment }\end{array}$ \\
\hline Non-U.S. party & $\begin{array}{c}-0.132 \\
(1.11)\end{array}$ & $\begin{array}{l}0.217^{*} \\
(2.09)\end{array}$ & $\begin{array}{c}-0.182+ \\
(1.67)\end{array}$ \\
\hline No forum & $\begin{array}{l}-2.939 * * \\
(5.94)\end{array}$ & $\begin{array}{l}-2.060 * * \\
(4.32)\end{array}$ & $\begin{array}{c}-1.514^{*} \\
(2.55)\end{array}$ \\
\hline DE forum & $\begin{array}{l}1.211 * * \\
(2.82)\end{array}$ & $\begin{array}{l}1.059^{*} \\
(2.45)\end{array}$ & $\begin{array}{l}1.018^{*} \\
(2.50)\end{array}$ \\
\hline FL forum & $\begin{array}{c}0.411 \\
(1.38)\end{array}$ & $\begin{array}{c}0.074 \\
(0.25)\end{array}$ & $\begin{array}{c}0.278 \\
(1.03)\end{array}$ \\
\hline IL forum & $\begin{array}{l}1.228 * * \\
(4.10)\end{array}$ & $\begin{array}{l}1.200 * * \\
(3.77)\end{array}$ & $\begin{array}{l}1.239 * * \\
(4.25)\end{array}$ \\
\hline MA forum & $\begin{array}{c}-0.320 \\
(0.92)\end{array}$ & $\begin{array}{c}0.049 \\
(0.14)\end{array}$ & $\begin{array}{c}0.260 \\
(0.85)\end{array}$ \\
\hline NY forum & $\begin{array}{l}0.814^{* *} \\
(3.63)\end{array}$ & $\begin{array}{l}0.733 * * \\
(3.22)\end{array}$ & $\begin{array}{l}0.763 * * \\
(3.62)\end{array}$ \\
\hline $\mathrm{OH}$ forum & $\begin{array}{l}1.011 * * \\
(2.60)\end{array}$ & $\begin{array}{l}0.955^{*} \\
(2.47)\end{array}$ & $\begin{array}{l}0.692+ \\
(1.91)\end{array}$ \\
\hline TX forum & $\begin{array}{c}-0.152 \\
(0.54)\end{array}$ & $\begin{array}{c}0.048 \\
(0.18)\end{array}$ & $\begin{array}{c}-0.349 \\
(1.33)\end{array}$ \\
\hline Other forum & $\begin{array}{c}0.453+ \\
(1.66)\end{array}$ & $\begin{array}{c}0.502+ \\
(1.82)\end{array}$ & $\begin{array}{c}0.223 \\
(0.86)\end{array}$ \\
\hline \multicolumn{4}{|c|}{ CA forum (reference category) } \\
\hline High standardization & $\begin{array}{l}0.326^{*} \\
(2.04)\end{array}$ & $\begin{array}{l}-0.608^{* *} \\
(5.36)\end{array}$ & \\
\hline Medium standardization & $\begin{array}{c}0.027 \\
(0.18)\end{array}$ & $\begin{array}{l}-0.417^{* *} \\
(3.82)\end{array}$ & \\
\hline \multicolumn{4}{|c|}{ Low standardization (reference category) } \\
\hline Chamber fairness rank & $\begin{array}{l}0.034 * * \\
(2.68)\end{array}$ & $\begin{array}{l}0.030^{*} \\
(2.41)\end{array}$ & $\begin{array}{l}0.027 * \\
(2.24)\end{array}$ \\
\hline Asset sale purchase & & & $\begin{array}{c}-0.245+ \\
(1.75)\end{array}$ \\
\hline Bond indentures & & & $\begin{array}{l}-0.613^{*} \\
(2.04)\end{array}$ \\
\hline Credit commitments & & & $\begin{array}{l}0.621 * * \\
(3.96)\end{array}$ \\
\hline Employment contracts & & & $\begin{array}{l}-0.577^{*} \\
(2.35)\end{array}$ \\
\hline Licensing & & & $\begin{array}{c}-0.171 \\
(0.48)\end{array}$ \\
\hline Pooling service & & & $\begin{array}{c}-0.247 \\
(0.94)\end{array}$ \\
\hline Securities purchase & & & $\begin{array}{c}-0.177 \\
(1.64)\end{array}$ \\
\hline
\end{tabular}


Table 11: Continued

\begin{tabular}{|c|c|c|c|}
\hline & $\begin{array}{c}1 \\
\text { No Separate } \\
\text { Arbitration Clause } \\
\text { Treatment }\end{array}$ & $\begin{array}{c}2 \\
\text { Arbitration } \\
\text { Clauses Treated } \\
\text { as Waivers }\end{array}$ & $\begin{array}{c}3 \\
\text { No Separate } \\
\text { Arbitration Clause } \\
\text { Treatment }\end{array}$ \\
\hline Security agreements & & & $\begin{array}{l}0.775^{* *} \\
(3.19)\end{array}$ \\
\hline Settlements & & & $\begin{array}{c}-0.282 \\
(1.27)\end{array}$ \\
\hline Underwriting & & & $\begin{array}{l}-0.684^{* *} \\
(3.90)\end{array}$ \\
\hline Other contract & & & $\begin{array}{c}-0.011 \\
(0.09)\end{array}$ \\
\hline \multicolumn{4}{|c|}{ Mergers (reference category) } \\
\hline Pseudo $R^{2}$ & 0.334 & 0.227 & 0.325 \\
\hline$N$ & 2,274 & 2,274 & 2,723 \\
\hline
\end{tabular}

Note: Constants included in models but not reported; contracts of type "Other" omitted from Models 1 and 2. Robust $z$ statistics in parentheses; +significant at $10 \%$; *at 5\%, **at $1 \%$. Probability weights account for the one month of additional sampling of merger contracts and models include, but do not report, dummy variables for industry groups. Models adjust for endogeneity of NO FORUM by using preliminary probit regressions of NO FORUM as a function of contract type, non-U.S. party, and attorney locale, and adjusting in the waiver equations for the probability of a forum selection clause being present.

Sources: U.S. Chamber of Commerce State Liability Systems Ranking Study, Final Report, January 11, 2002 (Study No. 14966); SEC EDGAR database, LEXIS EDGAR PLUS database, January 2002 to June 30, 2002 for contracts other than mergers, January 2002 to July 31, 2002 for mergers.

variable, as suggested by Table 3 and Figure 5. Models 1 and 3 provide for no special treatment of contracts with arbitration clauses. Model 2 treats the presence of an arbitration clause as a waiver of jury trial. ${ }^{58}$ Model 3 differs from Model 1 in its treatment of contract types. Model 1 uses our contract standardization measures as explanatory variables. Model 3 uses dummy variables for the contract types instead. All models include the NON-U.S. PARTY variable, the state forum dummy variables, and the Chamber of Commerce jury-fairness ranking as explanatory variables in the waiver

\footnotetext{
${ }^{58}$ Other models, not reported here, exclude from the sample contracts with arbitration clauses. These models explore whether the 80 percent of contracts that do not have arbitration clauses waive jury trials. They do not yield results materially different from those reported here.
} 
equation. The models include, but we do not separately report, dummy variables for the major industry groups summarized in Table 10. ${ }^{59}$

As suggested by Table 3 and Figure 5, the NO FORUM variable is statistically significant in explaining the absence of a jury trial waiver. Table 11 also shows substantial choice of forum effects. In Models 1 and 3, Delaware, Illinois, New York, and Ohio are significantly or nearly significantly more likely to contain jury waiver clauses than the reference state, California. These results are consistent with Table 3's simple results. The size of the Illinois effect is striking. For example, a marginal effects estimate indicates that it increases the probability of a jury trial waiver by approximately $0.40 .^{60}$ The relatively low rate of California jury trial waivers may be due to California's judicial limitation on the enforceability of jury waivers. ${ }^{61}$ That limitation was established after the period of our study but may have been anticipated by sophisticated parties.

The Chamber of Commerce's ranking of jury fairness is significantly associated with jury trial waivers. As the Chamber ranks a forum less fair, contracts that designate that forum tend to waive jury trials, confirming Figure 3's pattern. Industry effects, not separately reported, as a whole are statistically significant. In Model 1, for example, a test of the hypothesis that the industry dummy variables are jointly 0 yields a $p$ value of less than 0.001 . Construction companies are the most likely to have jury trial waivers. Paper and allied products companies are the least likely.

Model 1 also includes our measures of contract standardization, as represented by the dummy variables HIGH STANDARDIZATION and MEDIUM STANDARDIZATION, with LOW STANDARDIZATION as the reference category. Both standardization variables are associated with increased likelihood of a jury trial waiver clause and the HIGH STANDARDIZATION variable is statistically significant. In Model 3, several of the contract-type dummy variables are statistically significant and the results are largely consistent with Table 2's description of the relation between contract types and jury trial waiver.

\footnotetext{
${ }^{59}$ The variable constructed to correct for endogeneity, not reported, is statistically significant $(p<0.01)$ in the three models.

${ }^{60}$ Figure 5 suggests that the Illinois effect is felt most prominently, highest up in the classification tree, in securities purchase contracts.

${ }^{61}$ See supra note 1.
} 
Some results change in size and/or direction in Model 2, which treats arbitration clauses as the equivalent of jury trial waivers. The sign on the HIGH STANDARDIZATION variable changes in Model 2. This is consistent with Figure 2's showing that the relation between contract standardization and arbitration clause rates differs from the relation between standardization and jury trial waiver rates. Model 2's coefficient for NON-U.S. PARTY shows that international contracts are significantly more likely than domestic contracts to avoid jury trials by either arbitration clauses or jury trial waiver clauses. The opposite sign on this variable in Models 1 and 3 shows that this effect is attributable to the treatment of contracts with arbitration clauses. When they are not treated as jury trial waivers, international contracts are mildly less likely than domestic contracts to contain jury waivers.

\section{Discussion of Results}

Sections IV and V contain two separable classes of results. The first and principal result is that sophisticated parties tended to preserve access to jury trials when they could agree to avoid the risks of such trials. Second are a set of results suggesting the factors that influence the decision to include contract clauses waiving jury trials. These results provide a deeper understanding of the minority of contracts in which parties shun juries.

\section{A. Contracting Parties' Preservation of Access to Jury Trials}

A rich academic literature explores the possible advantages and disadvantages of juries as finders of fact. One set of studies raises questions about the efficiency or fairness of the jury. For example, studies suggest that juries may give undue weight to eyewitness testimony, ${ }^{62}$ statements against interest, ${ }^{63}$

\footnotetext{
${ }^{62}$ See, e.g., John C. Brigham \& Robert K. Bothwell, The Ability of Prospective Jurors to Estimate the Accuracy of Eyewitness Identifications, 7 Law \& Hum. Behav. 19 (1983) (mock jurors predicted that eyewitness testimony was 71 percent accurate when actual accuracy rate was only 13 percent); Gary L. Walls et al., Accuracy, Confidence and Jury Perceptions in Eyewitness Identification, 64 J. Applied Psychology 440 (1979). Juries may be especially swayed if the expert couches his or her testimony in highly technical terms. See Irwin A. Horowitz, Kenneth S. Bordens, Elizabeth Victor, Martin J. Bourgeois \& Lynne Forster Lee, The Effects of Complexity on Jurors' Verdicts and Construction of Evidence, 86 J. Applied Psychol. 641, 649 (2001).
}

${ }^{63}$ Saul M. Kassin, The Psychology of Confession Evidence, 52 Am. Psychologist 221 (1997). 
and expert opinions, ${ }^{64}$ and may unduly discount forensic evidence such as DNA matches. ${ }^{65}$ Juries may misunderstand circumstantial evidence ${ }^{66}$ or fail to reach a correct result in circumstantial cases even when they understand the probative value of the evidence. ${ }^{67}$ Jurors may be influenced by the personality of the lawyers, the physical appearance of the parties, ${ }^{68}$ or the size of the requested damages award, ${ }^{69}$ and may decide on the basis of inappropriate factors such as dislike for business litigants ${ }^{70}$ or moral judgments about a party's conduct. ${ }^{71}$ Jurors may be subject to cognitive shortcomings such as

\footnotetext{
${ }^{64}$ Allan Raitz, Edith Greene, Jane Goodman \& Elizabeth F. Loftus, Determining Damages: The Influence of Expert Testimony on Jurors' Decision Making, 14 Law \& Hum. Behav. 385, 393 (1990).
}

${ }^{65}$ Dale A. Nance \& Scott B. Morris, Juror Understanding of DNA Evidence: An Empirical Assessment of Presentation Formats for Trace Evidence with a Relatively Small Random-Match Probability, 34 J. Legal Stud. 395 (2005).

${ }^{66}$ See, e.g., William C. Thompson \& Edward L. Schumann, Interpretation of Statistical Evidence in Criminal Trials, 11 Law \& Hum. Behav. 167 (1987) (66 percent of mock jurors significantly underestimated the probative value of blood evidence).

${ }^{67}$ See, e.g., Gary L. Wells, Naked Statistical Evidence of Liability: Is Subjective Probability Enough? 62 Personality \& Soc. Psychol. 739 (1992).

${ }^{68}$ See, e.g., Catherine T. Harris, Ralph Peeples \& Thomas B. Metzloff, Placing "Standard of Care" in Context: The Impact of Witness Potential and Attorney Reputation in Medical Malpractice Litigation, 3 J. Empirical Legal Stud. 467 (2006) (when liability was rated as uncertain or unlikely, strategic variables such as perceived witness potential and the reputation of the plaintiff's counsel were significant predictors of case outcome); Robert J. MacCoun, The Emergence of Extralegal Bias During Jury Deliberation, 17 Crim. Just. \& Behav. 303, 311 (1990) (mock juries were more likely to acquit when the defendant was physically attractive).

${ }^{69}$ Cass Sunstein et al., Punitive Damages: How Juries Decide (2002); Gretchen B. Chapman \& Brian H. Bornstein, The More You Ask for, the More You Get: Anchoring in Personal Injury Verdicts, 10 Applied Cognitive Psychol. 519, 538 (1996).

${ }^{70}$ Sunstein et al., supra note 69 .

${ }^{71}$ Edith Greene, Michael Johns \& Alison Smith, The Effects of Defendant Conduct on Jury Damage Awards, 86 J. Applied Psychol. 228 (2001). 
hindsight bias ${ }^{72}$ imperfect attention spans,${ }^{73}$ limited memories, confusion as to the identities of multiple plaintiffs, ${ }^{74}$ and inability to understand or implement the trial court's instructions on the law. ${ }^{75}$ In consequence, they may reach different results in similar cases and, occasionally, award damages that are hard to justify based on the facts of a case. ${ }^{76}$

Other studies evince a more optimistic assessment of the value and accuracy of jury decisions. For example, despite the widespread belief that jury awards of punitive damages are arbitrary and excessive, numerous studies find that jury awards of punitive damages are not increasing in frequency or size and are not arbitrary. ${ }^{77}$ Treatment of corporations may also be more nuanced than critics suggest: juries do not always rule against "deep-pocket" defendants, even when the beneficiary of such a ruling would be a sympathetic individual plaintiff. ${ }^{78}$ Moreover, the fact that juries may be

\footnotetext{
${ }^{72}$ Sunstein et al., supra note 69; Susan J. Lebine \& Gary LaBine, Determinations of Negligence and the Hindsight Bias, 20 Law \& Hum. Behav. 501 (1996) (study participants were more likely to find the therapist negligent when informed that the patient had in fact become violent).
}

${ }^{73}$ Phoebe C. Ellsworth, Some Steps Between Attitudes and Verdicts, in Inside the Juror: The Psychology of Juror Decision Making 42-43 (Reid Hastie ed., 1993).

${ }^{74}$ Lynne Forster Lee, Irwin A. Horowitz \& Martin J. Bourgeois, Juror Competence in Civil Trials: Effects of Preinstruction and Evidence Technicality, 78 J. Applied Psychol. 14, 19 (1993).

${ }^{75}$ Sunstein et al., supra note 69; Judith L. Ritter, Your Lips Are Moving . . . But the Words Aren't Clear: Dissecting the Presumption that Jurors Understand Instructions, 69 Mo. L. Rev. 163, 164 (2004).

${ }^{76}$ Sunstein et al., supra note 69 .

${ }^{77}$ E.g., Theodore Eisenberg, Paula L. Hannaford-Agor, Michael Heise, Neil LaFountain, G. Thomas Munsterman, Brian Ostrom \& Martin T. Wells, Juries, Judges, and Punitive Damages: Empirical Analyses Using the Civil Justice Survey of State Courts 1992, 1996, and 2001 Data, 3 J. Empirical Legal Stud. 263, 266 n.8 (2006) (collecting authorities); Theodore Eisenberg \& Martin T. Wells, The Significant Association Between Punitive and Compensatory Damages in Blockbuster Cases: A Methodological Primer, 3 J. Empirical Legal Stud. 169 (2006).

${ }^{78}$ See Valerie P. Hans, Business on Trial: The Civil Jury and Corporate Responsibility (2000); Robert J. MacCoun, Differential Treatment of Corporate Defendants by Juries: An Examination of the "Deep-Pockets" Hypothesis, 30 Law \& Soc'y Rev. 121, 143 (1996) ("existing evidence argues against a deep-pocket interpretation of jury verdict patterns"); Valerie P. Hans, The Jury's Response to Business and Corporate Wrongdoing, 52 Law \& Contemp. Probs. 177, 202 (1989) ("juries show remarkable restraint in judging corporate culpability"); Valerie P. Hans, The Contested Role of the Civil Jury in Civil Litigation, 79 Judicature 242, 248 (1996) ("deep pockets explanation ... does not fare well in this set of studies"). 
imperfect is not, in itself, a sufficient reason for rejecting them as finders of fact, since judges are also subject to cognitive biases ${ }^{79}$ and to the influence of emotion or prejudice. ${ }^{80}$ Indeed, because there is only one judge, but multiple jurors, the possibility of inaccurate results may in some respects be greater in a bench trial because the group-decision process of a civil jury tends to control for outliers. ${ }^{81}$ Thus, to the degree that juries and judges differ, there is no a priori reason to conclude that judges are the more accurate. ${ }^{82}$

Our study sheds light on this debate, at least as it pertains to the value of civil juries in cases involving large commercial contracts. As noted elsewhere ${ }^{83}$ the contracts in our sample constitute or are connected with events that are material to the financial conditions of publicly traded corporations. It is reasonable to assume that they receive care and attention during negotiation and drafting from the reporting firm's employees or from outside counsel (or both). Because the contracts are negotiated before disputes arise, moreover, we can infer that in most cases the contracting parties did not anticipate the precise nature of any dispute that might arise, and therefore would not know whether a particular term would help or hurt them in the event of a conflict. Thus if jury trials create greater uncertainty or generate higher costs than other mechanisms for resolving disputes, well-

\footnotetext{
${ }^{79}$ Chris Guthrie, Jeffrey J. Rachlinski, Andrew J. Wistrich, Inside the Judicial Mind, 80 Cornell L. Rev. 777, 802-03 (2001) (finding that judges are subject to hindsight bias).

${ }^{80}$ See David S. Abrams, Marianne Bertrand \& Sendhil Mullainathan, Do Judges Vary in Their Treatment of Race? (manuscript, Apr. 2006) (judges may display racial bias in criminal sentencing).

${ }^{81}$ On the other hand, in the case of the jury, there is the possibility that group pressures could negatively affect the reliability of decisions. See M. Neil Browne, Carrie Williamson \& Garrett Coyle, The Shared Assumptions of the Jury System and the Market System, 50 St. Louis Univ. L.J. 425, 466 (2006).
}

\begin{abstract}
${ }^{82}$ Evidence suggests that systematic differences exist between judges and juries as factfinders, even though much agreement also exists. For example, judges are more likely to convict in criminal cases. Theodore Eisenberg, Paula L. Hannaford-Agor, Valerie P. Hans, Nicole L. Waters, G. Thomas Munsterman, Stewart J. Schwab \& Martin T. Wells, Judge-Jury Agreement in Criminal Cases: A Partial Replication of Kalven \& Zeisel's The American Jury, 2 J. Empirical Legal Stud. 171 (2005). However, studies find no systematic differences between judges and juries in the relation between punitive and compensatory damages. E.g., Eisenberg et al., Juries, Judges, and Punitive Damages, supra note 77.
\end{abstract}

${ }^{83}$ Eisenberg \& Miller, Merger, supra note 21; Eisenberg \& Miller, Arbitration, supra note 16. 
informed and sophisticated parties may be expected to forego them as a matter of course. On the other hand, if jury trials are not perceived to be inferior to other dispute-resolution mechanisms, then such parties will not uniformly opt out. In the absence of significant transactions costs or thirdparty effects, moreover, parties bargaining for mutual advantage will tend to agree to provisions that maximize the social surplus. ${ }^{84}$ Such bargaining includes provisions regarding the resolution of disputes that might arise under the contract. ${ }^{85}$ Thus the observed behavior of the contracting parties-such as the data presented in this study-provides information about the social benefits as well as the private value of jury trials.

The evidentiary value of our study is contingent on several factors. First, the alignment between the outcome of private bargaining and social surplus will potentially be undermined if the outcome of that process affects the interests of third parties not present at the bargaining table. However, externalities would appear to be relatively modest in the case of the large commercial contracts under review here, and even when externalities are present, they have no obvious bearing on the issue of jury trial waiver. ${ }^{86}$

Second, the observed contract terms may not align with social welfare if agency costs are significant-if the attorneys who negotiate and draft the contracts serve their own interests at the expense of their clients. It is possible to conjecture some agency costs. For example, if jury trials are more expensive and risky than bench trials, it may be in lawyers' self-interest to preserve them as a dispute-resolution possibility in order to earn larger fees in the event the contract becomes disputed and the drafting attorney is chosen to litigate the matter. Although this possibility cannot be ruled out, it seems

\footnotetext{
${ }^{84}$ Ronald J. Gilson, Value Creation by Business Lawyers: Legal Skills and Asset Pricing, 94 Yale L.J. 239 (1984). This is true even if a jury trial would predictably benefit one of the contracting parties at the expense of the other. See, e.g., David S. Steuer, A Litigator's Perspective on the Drafting of Commercial Contracts (PLI Dec. 2004-Jan. 2005). Even if it is known ex ante that a jury trial would benefit one party at the expense of the other, if overall it is more efficient than a bench trial, both parties can make themselves better off by agreeing not to waive the jury, with the disadvantaged party receiving a more than compensatory setoff in some other term of the contract.

${ }^{85}$ See, e.g., Keith Hylton, Agreements to Waive or to Arbitrate Legal Claims: An Economic Analysis, 8 Sup. Ct. Econ. Rev. 209 (2000); Steven Shavell, Alternative Dispute Resolution: An Economic Analysis, 24 J. Legal Stud. 1, 5 (1995).

${ }^{86}$ In general, an agreement to waive a jury trial would not bind third parties not party to or in privity with a party to the contract.
} 
strained to suggest that it often plays a decisive role in attorney decisions, especially given that the contracting entities in our sample are sophisticated parties that usually have access to the advice of capable in-house counsel. Other than such speculative effects, it is hard to identify a strong self-interest that would induce an attorney to seek or eschew an agreement on jury trials that would harm the interests of his or her client.

Third, our sample may not provide reliable evidence of efficient dispute-resolution terms if the transactions costs of the bargaining itself prevent the parties from achieving an optimal substantive result. One hypothesis could be that the issue of jury trial waivers is one of de minimis importance, so that lawyers negotiating contracts do not actively consider or decide whether to include a waiver or not. ${ }^{87}$ We cannot rule out the possibility that jury trial waivers are mere matters of "boilerplate" that receive no scrutiny or consideration by the contracting parties, but we consider this to be unlikely for contracts in our sample. These large commercial contracts constitute all or part of transactions deemed to be material to the affairs of SEC-reporting companies. The contract dispute-resolution provisions should be important enough to receive attention from the attorneys. Jury trial waivers are included in a significant number of contracts that appear to be individually negotiated (e.g., settlement of disputes). Even when the contract in question is highly standardized (e.g., pooling and servicing agreements), the model on which the contract is based likely has been thoroughly considered by sophisticated business lawyers. Jury trial waivers do, in fact, become important issues in litigation, and have generated many judicial decisions. ${ }^{88}$ Accordingly, the presence or absence of a jury trial waiver in a sophisticated commercial contract will often reflect considered judgments about what arrangement best serves the joint interests of the contacting parties.

\footnotetext{
${ }^{87}$ In such cases, if no mention is made in the contract, a jury trial would ordinary be available in lawsuits for contract damages. Or if the attorney utilizes a model or form that contains a jury trial waiver, a jury may be foregone, although without active consideration by the parties. Jury trial waivers are contained in some model contracts. See, e.g., Ted A. Donner, Attorney's Practice Guide to Negotiations § 14:29. Sample agreements—Business agreement (2006) ("The parties agree that any dispute hereunder shall be resolved by bench trial and waive the right to any trial by jury hereunder."); 2 Model Agreements for Corporate Counsel § 16:13 ("The parties hereby expressly waive any right they may have to a trial by jury for any dispute arising out of or related to this agreement.") (capitalization omitted).
}

${ }^{88}$ See, e.g., cases cited supra note 1. 
Another transactions-cost hypothesis for the paucity of jury trial waivers would accept that jury trial waivers are important enough for lawyers to consider, but that the lawyers lack access at reasonable cost to information necessary for a well-informed judgment about whether to waive juries. Thus their failure to waive jury trials may provide no new information. It is certainly true, as noted above, that disagreement exists among informed opinion about the value of juries. Yet business lawyers who simply accept received wisdom should follow publicly expressed attitudes within the business community and preclude juries altogether. The fact they do not-and in fact reject juries far less than half the time-suggests that they may be acting according to some reliable information that juries often do enhance the value of commercial contracts.

Finally, strategic factors should also be considered in assessing the degree to which the low rate of jury trial waivers in our sample is evidence of the economic value of juries in commercial cases. For example, it could be that transaction costs associated with jury trial are desired by the parties as penalties against too-easy breaches of contract. ${ }^{89}$

Notwithstanding these caveats, we believe that the behavior of sophisticated contacting parties with respect to jury trial waivers provides information pertinent to the debate about the value of civil juries in commercial cases. Our data showing that such parties more often than not fail to opt out of jury trials suggest that the availability of a jury trial often enhances the joint welfare of the contracting parties. Thus, our data provide evidence that juries often provide economic value for the parties and for society as a whole, quite apart from other reasons that may exist for the institution of the civil jury. ${ }^{90}$ If some of the world's best-advised, most sophisticated legal actors implicitly recognize juries' value, the case for anti-jury legal reform is weakened.

\footnotetext{
${ }^{89}$ See, e.g., Maurits Barendrecht \& Berend R. de Vries, Fitting the Forum to the Fuss with Sticky Defaults: Failure on the Market for Dispute Resolution Services? 7 Cardozo J. Conflict Resol. 83 (2005); David M. Driesen \& Shubha Ghosh, The Functions of Transaction Costs: Rethinking Transaction Cost Minimization in a World of Friction, 47 Ariz. L. Rev. 61 (2005).

${ }^{90}$ See, e.g., Hans, The Contested Role, supra note 78, at 248 (observing that at a time when the balance between corporate and individual responsibility is in flux, juries "reflect community notions of both individual and corporate responsibility," respond to changing norms, and convey information about the public's vision of sound corporate conduct).
} 


\section{B. Explaining the Pattern of Jury Trial Waiver Clauses}

Although jury trial waivers are relatively rare, they are strongly associated with type of contract. The high rates of waiver in credit commitments and security agreements may reflect lender beliefs that juries are more likely than judges to impose lender liability. The low rate in employment contracts may reflect doubt about underlying enforceability in contests between large corporations and individuals. The low rates of waiver in the least standardized contracts-employment, licensing, and settlements-may suggest that jurors' perspectives are especially valued when problems of contract interpretation are likely to be less mechanical. Perhaps the parties value juries' perceived inclination to avoid strict contractual interpretations when they perceive themselves as possibly unfairly suffering from such interpretations.

A striking result is the 80 percent rate of jury trial waivers in contracts designating Illinois as a litigation forum. This far exceeds the waiver rate in other large, commercially important states. Two factors appear to contribute to this result. First, Figure 4 and the related discussion indicate that Illinois has an extremely long difference in time to adjudication between jury trials and bench trials. Jury trials take substantially longer to adjudicate in Chicago, relative to bench trials, than the relative time they take in other places. Although the difference in jury and bench trial time of adjudication did not help explain the overall pattern of jury trial waivers, the difference likely does contribute to the Illinois result. Second, Figure 3 suggests that large corporations perceive Illinois juries to be among the least fair. The combination of efficiency and fairness factors may explain the high Illinois jury trial waiver rate. ${ }^{91}$

We are mindful that, like our study of arbitration clauses, ${ }^{92}$ this is the first study of its kind and it is important to recognize its limitations. The contracts we study exist in a narrow time period. Ideally, we would like information for periods before and after the first half of 2002. The variation

\footnotetext{
${ }^{91}$ Also of interest at the individual-state level is the fairly high rate of jury trial waiver clauses in Georgia. See Figure 3. This is noteworthy because Georgia's highest court in 1994 found such waivers to be unenforceable. Bank S., N.A. v. Howard, 264 Ga. 339, 444 S.E.2d 799 (1994). Yet five of nine contracts specifying Georgia as the litigation forum included jury trial waivers. Perhaps the attorneys who drafted these contracts considered that their clients had little to lose from a waiver because in the worst case it would simply not be enforced and the litigation would be treated as if no such waiver had been present.
}

${ }^{92}$ Eisenberg \& Miller, Arbitration, supra note 16. 
across contract types in the rates of jury trial waiver also suggests that more information and more sophisticated modeling of the decision to include waivers could be fruitful. The details of the relations between the contracting parties and the motivations of those drafting the clauses should be studied.

\section{Conclusion}

We present evidence that large corporate actors do not systematically flee juries even though they have the ability to do so, at low expense, by waiving jury trials ex ante in their contracts. International contracts also include jury trial waivers at a surprisingly low rate. Contract types are strongly associated with jury trial waivers, with the waiver rate ranging from near-zero in bond indentures, employment contracts, pooling service agreements, and underwriting contracts to over 50 percent in credit commitments and security agreements. Parties appear to vary the decision whether to include a choice of forum in a contract and then to include a jury trial waiver based in part on the forum chosen. Contracts specifying Illinois as a forum waive jury trials 80 percent of the time while contracts designating New York, California, Texas, and Florida as a forum do so less than 50 percent of the time. Parties tend to waiver jury trials more when the forum chosen is perceived to have unfair juries.

In the simple economic view, our results suggest that juries can add value to complex commercial adjudication. Contracting parties appear to consider the desirability of waiving juries, as evidenced by the greater waiver rates in states that the Chamber of Commerce ranks as having less fair juries. Failure to waive jury trials is therefore not accidental; the parties likely assign a positive value to the availability of jury trial. Because predispute jury trial waivers occur ex ante, their relative infrequency provides evidence that juries may often confer social as well as private benefits as compared with the available alternatives of fact finding by judges or arbitrators. 


\section{Appendix: Jury Trial Waiver by Whether Forum Specified And Contract Type}

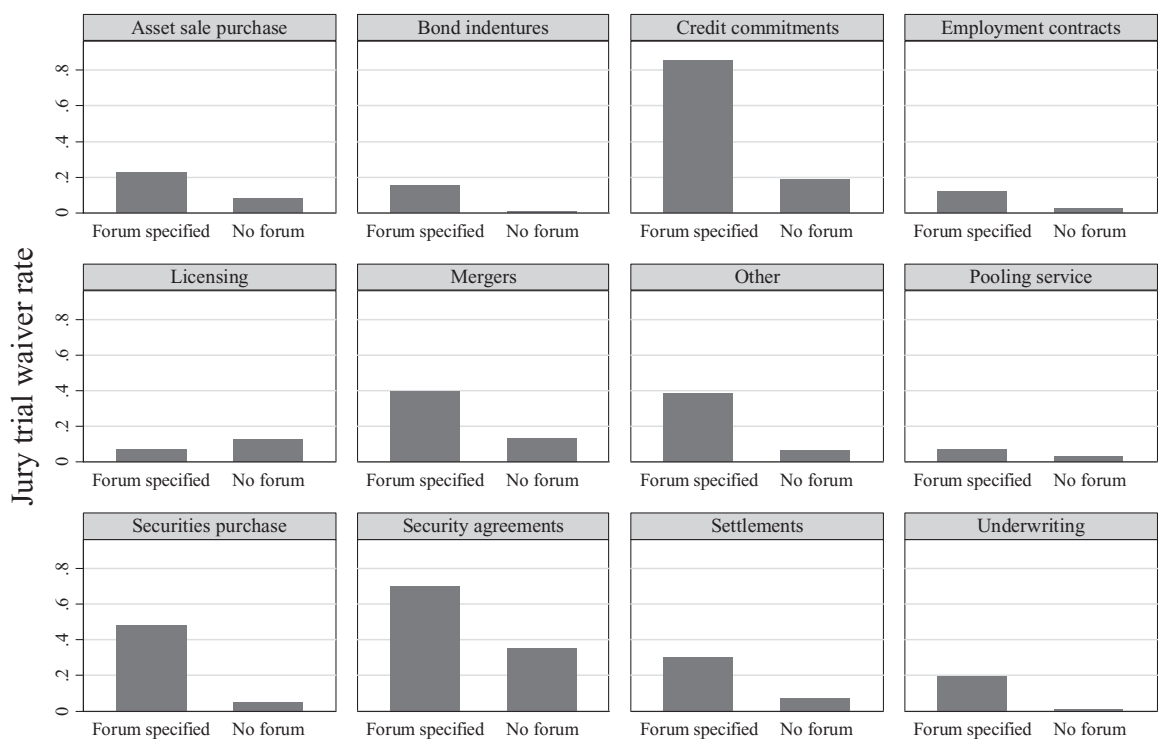

Sources: BJS data on trial outcomes in 46 large counties, 2001; SEC EDGAR database, LEXIS EDGAR PLUS database, January 2002 to June 30, 2002 for all contract types other than mergers and January 2002 to July 31, 2002 for merger contracts. 